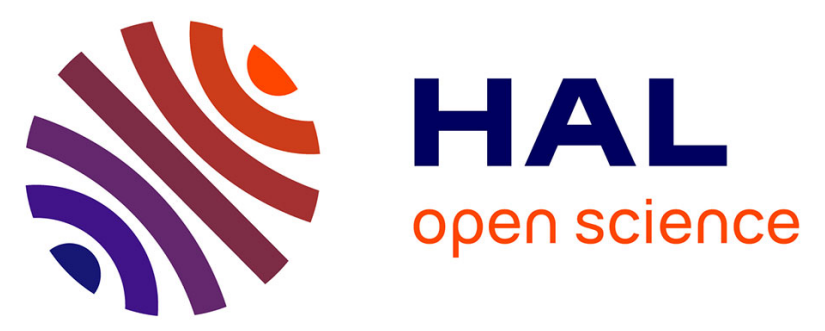

\title{
Adaptive response under multiple stress exposure in fish: From the molecular to individual level
}

Allison Gandar, Pascal Laffaille, Cécile Canlet, Marie Tremblay-Franco, Roselyne Gautier, Annie Perrault, Laure Gress, Pierre Mormède, Nathalie Tapie, Hélène Budzinski, et al.

\section{To cite this version:}

Allison Gandar, Pascal Laffaille, Cécile Canlet, Marie Tremblay-Franco, Roselyne Gautier, et al.. Adaptive response under multiple stress exposure in fish: From the molecular to individual level. Chemosphere, 2017, 188, pp.60-72. 10.1016/j.chemosphere.2017.08.089 . hal-01613631

\section{HAL Id: hal-01613631 https://hal.science/hal-01613631}

Submitted on 26 May 2020

HAL is a multi-disciplinary open access archive for the deposit and dissemination of scientific research documents, whether they are published or not. The documents may come from teaching and research institutions in France or abroad, or from public or private research centers.
L'archive ouverte pluridisciplinaire HAL, est destinée au dépôt et à la diffusion de documents scientifiques de niveau recherche, publiés ou non, émanant des établissements d'enseignement et de recherche français ou étrangers, des laboratoires publics ou privés. 


\section{Accepted Manuscript}

Adaptive response under multiple stress exposure in fish: From the molecular to individual level

Allison Gandar, Pascal Laffaille, Cécile Canlet, Marie Tremblay-Franco, Roselyne Gautier, Annie Perrault, Laure Gress, Pierre Mormède, Nathalie Tapie, Hélène

Budzinski, Séverine Jean

PII:

$$
\text { S0045-6535(17)31311-5 }
$$

DOI:

10.1016/j.chemosphere.2017.08.089

Reference: CHEM 19787

To appear in: $E C S N$

Received Date: 7 April 2017

Revised Date: 31 July 2017

Accepted Date: 18 August 2017

Please cite this article as: Gandar, A., Laffaille, P., Canlet, Cé., Tremblay-Franco, M., Gautier, R., Perrault, A., Gress, L., Mormède, P., Tapie, N., Budzinski, Héè., Jean, Sé., Adaptive response under multiple stress exposure in fish: From the molecular to individual level, Chemosphere (2017), doi: 10.1016/j.chemosphere.2017.08.089.

This is a PDF file of an unedited manuscript that has been accepted for publication. As a service to our customers we are providing this early version of the manuscript. The manuscript will undergo copyediting, typesetting, and review of the resulting proof before it is published in its final form. Please note that during the production process errors may be discovered which could affect the content, and all legal disclaimers that apply to the journal pertain. 
1 Adaptive response under multiple stress exposure in fish: from the molecular to

2 individual level

3

4 Allison Gandar ${ }^{a}$, Pascal Laffaille ${ }^{a}$, Cécile Canlet ${ }^{b}$, Marie Tremblay-Franco ${ }^{b}$, Roselyne Gautier ${ }^{b}$, Annie Perrault

$5{ }^{a}$, Laure Gress ${ }^{c}$, Pierre Mormède ${ }^{c}$, Nathalie Tapie ${ }^{d}$, Hélène Budzinski ${ }^{d}$, Séverine Jean ${ }^{a *}$.

6

$7 \quad{ }^{a}$ EcoLab, Université de Toulouse, CNRS, INPT, UPS, Toulouse, France

$8 \mathrm{~b}^{\mathrm{b}}$ Toxalim (Research Centre in Food Toxicology), Université de Toulouse, INRA, ENVT, INP-Purpan, UPS,

9 Toulouse, France.

$10{ }^{\mathrm{c}}$ GenPhySE, Université de Toulouse, INRA, INPT, INP-ENVT, Castanet Tolosan, France

$11{ }^{d}$ LPTC, Molecular Sciences Institute (ISM) Université Bordeaux 1, CNRS, Talence, France

* corresponding author: severine.jean@ensat.fr 
Aquatic systems are subjected to various sources of stress due to global changes, such as increasing temperature and pollution. A major challenge for the next decade will be to evaluate the combined effects of these multiple stressors on organisms and ecosystems. For organisms submitted to chemical, biological or

17 physical stressors, the capacity to set up an efficient adaptive response is a fundamental prerequisite for their 18 long-term survival and performance. In this study, goldfish (Carassius auratus) were subjected to individual 19 and combined pesticide mixtures and increased temperatures to evaluate their adaptive response in 20 multistress conditions from the molecular to the individual level. Fish were exposed for 16 days to a mixture of 21 pesticides at environmental relevant concentrations (S-metolachlor, isoproturon, linuron, atrazine-desethyl, 22 aclonifen, pendimethalin and tebuconazole) and at two temperatures $\left(22{ }^{\circ} \mathrm{C}\right.$ and $\left.32{ }^{\circ} \mathrm{C}\right)$. Three major 23 physiological traits of the stress response were measured: the hormonal response (i.e. plasma cortisol), the 24 metabolic balance from molecular to individuals' levels (metabolomics, cellular energy allocation, energy reserves and global condition indexes), and the cellular defense system induction (SOD, CAT and GST). Results show that (1) environmentally relevant concentrations of pesticides lead to significant responses in fish at all 27 biological levels; (2) the metabolic response depends on the nature of stress (thermal vs. chemical); and (3) 28 fish may be unable to set up an efficient adaptive response when chemical and thermal stresses were combined, with adverse outcomes at the individuals' level.

30 Keywords: Pesticides mixtures, Climate Change, Temperature, Metabolomics, Nuclear Magnetic Resonance NMR, Oxidative stress, Goldfish 
Global changes are increasingly exposing aquatic systems to multiple stressors, but predicting their

effects on aquatic organisms at different biological levels remains a challenge. The stress response is a set of adaptive physiological responses of organisms submitted to a stimulus (a stressor) perceived as dangerous, that helps maintaining homeostasis (Selye, 1950; Barton, 2002). For this purpose, the activation of the sympathetic nervous system and Hypothalamic-Pituitary-Adrenal (HPA) axis initiates a cascade of physiological changes triggered by catecholamines (i.e. adrenaline) and corticosteroid (i.e. cortisol) stress hormones. When stress persists, organisms enter in a phase of resistance characterized by the induction of cellular defense systems (Selye, 1946; 1950). The bioenergetic cost of the defense is supported by metabolic trade-offs between maintenance, activity, growth, reproduction and energy storage (Calow, 1991; Handy et al., 1999; Marchand et al., 2004). When stress is chronic or exceeds the defense and compensation capacities, adverse effects on survival and fitness of organisms may occur (Selye, 1950; Barton, 2002).

France is the leading European country in terms of agricultural area (Alim'agri, 2012) and the fourth largest consumer of pesticides in the world (Bonnefoy, 2012). The 15 most frequently detected molecules in surface waters are herbicides and fungicides, essentially used to limit weeds production and control pathogen invasion in field crops and viticulture (Butault et al., 2010). While the adverse effects of insecticides on nontarget species are subject to a broad consensus within the scientific community, the toxicity of herbicides at environmentally relevant concentrations for aquatic vertebrates remains largely controversial (Solomon et al., 2008, 2013; Van Der Kraak et al., 2014). Previous studies focused almost exclusively on the effects of a single molecule. Studies on the effects of complex and realistic mixtures of pesticides on aquatic vertebrates are extremely rare, which can lead to a dramatic underestimation of the risks for wildlife (Hayes et al., 2006). At the same time, aquatic systems are submitted to environmental changes, such as increasing temperature. Interactions between contaminants and water temperature can be particularly deleterious for ectothermic species as the temperature directly affects many biochemical and physiological processes (López-Olmeda, and Sánchez-Vázquez, 2011; Manciocco et al., 2014). Higher temperature leads to increased energy demand. By affecting the metabolic level of individuals, the temperature can change the ability of aquatic organisms to effectively respond to chemical contamination, and vice versa (Lemly, 1996; Kennedy and Ross, 2012; Sokolova, 2013). The majority of studies thus shows a synergistic effect of temperature on the toxicity of pollutants, especially in aquatic species (Schiedek et al., 2007; Noyes et al., 2009; Holmstrup et al., 2010; Laetz et al., 2014). Inversely, the exposure to pollutants may affect the temperature tolerance in fish species (Manciocco et al., 2014). However, there is a lack of knowledge about combined effects between temperature and pesticide mixtures on aquatic vertebrates. In previous studies (Gandar et al., 2015, 2017), we exposed goldfish (Carassius auratus) to higher temperature and a mixture of herbicides and fungicides at realistic concentrations for 96 hours. Results showed significant cross effects between temperature and pesticides on behavioral responses, energy reserves and hepatic proteome profile, suggesting that combined thermal and 
chemical stressors impaired the stress response of the goldfish to individual stressors (Gandar et al., 2015, 2017). However, the effects of a longer exposure on fish global performance across biological levels remain to be determined.

Therefore, the aim of this study was to assess the adaptive response to stress of goldfish submitted to single and combined chemical and thermal stresses, integrating responses from the molecular to the whole organism level. To that end, goldfish were exposed during 16 days to a mixture of six herbicides (SMetolachlor, Isoproturon, Linuron, Aclonifen, Atrazine-desethyl and Pendimethalin) and one fungicide (Tebuconazol) to a total concentration of $42 \mu \mathrm{g} \cdot \mathrm{L}^{-1}$ at two temperatures $\left(22^{\circ} \mathrm{C}\right.$ and $32{ }^{\circ} \mathrm{C}$ ). The stress response was investigated at $6 \mathrm{~h}, 96 \mathrm{~h}$ and $16 \mathrm{~d}$ of exposure, including plasma cortisol concentration, hepatic induction of antioxidant enzymatic defenses (superoxide dismutase SOD, catalase CAT) and enzymatic system of detoxification Glutathion-S-Transferase (GST), hepatic metabolome response by ${ }^{1} \mathrm{H}-\mathrm{NMR}$ metabolomic analysis, energy reserves and cellular energy allocation in liver and white muscle, somatic indexes (muscle and hepatic indexes) and global condition of fish (Fulton's condition factor).

\section{Materials and methods}

\subsection{Pesticide mixture}

The objective of the study was to characterize fish responses to environmentally relevant pesticide mixtures at different temperatures. The mixture was developed on the basis of the pesticide contamination of the Save River (France), assessed from March 2008 to November 2009 (Polard et al., 2011) as described by Gandar et al. 2017. According to the analysis conducted by Pollard et al. (2011) and Taghavi et al. (2011), we selected six herbicides and one fungicide using three criteria: the frequency of detection, the concentration and the representation of the different families of molecules detected. Selected molecules are S-metolachlor, Isoproturon, Linuron, Tebuconazol, Aclonifen, Atrazine-desethyl and Pendimethalin (Supplementary Table 1).

Pesticide concentrations in water were measured after $16 \mathrm{~d}$ of exposure. Water samples of $1 \mathrm{~mL}$ were spiked with internal standards solution (Simazine D10, Atrazine-desethyl D7, Isoproturon D6, Linuron D6, Metolachlor D6, Pendimethalin D5, Tebuconazole D6) and directly analyzed on an Agilent liquid chromatographic system coupled with a triple quadrupole mass spectrometer (Agilent LC 1290 Infinity / 6460 Triple quadrupole) equipped with an electrospray ionization source used in positive mode (ESI+) (adapted from Gamain et al., 2016). Pesticides were quantified using a quantification transition. Analytical method was validated in terms of calibration linearity, specificity, and limits of quantifications $\left(0.005\right.$ to $\left.0.5 \mu \mathrm{g} . \mathrm{L}^{-1}\right)$. Recoveries of samples of fortified mineral water were evaluated for water analysis (from 89 to $116 \%$ ). Control calibrating standards were also injected every 15 samples and analytical blanks were performed. All solvents for chemicals analysis were at least of analytical grade. The measured concentration of pesticides showing a slight decrease compared to expected values (total concentration of $38.7 \mu \mathrm{g} \cdot \mathrm{L}^{-1}$, Supplementary Table 1 ). Pesticide standards were obtained from Sigma-Aldrich (St. Louis, MO, USA): S-metolachlor (CAS-No: 87392-12-9, 
PESTANAL ${ }^{\circledR}, 98,4 \%$ pure), Isoproturon (CAS-No: $34123-59-6$, PESTANAL ${ }^{\circledR}, 99 \%$ pure), Linuron (CAS-No: $330-55-$ 2, PESTANAL ${ }^{\circledR}, 99,7 \%$ pure), Atrazine-desethyl (CAS-No: 6190-65-4, PESTANAL ${ }^{\circledR}, 99,5 \%$ pure), Aclonifen (CASNo: 74070-46-5, PESTANAL ${ }^{\circledR}, 99,8 \%$ pure), Pendimethalin (CAS-No: 40487-42-1, PROWL ${ }^{\circledR}, 98,8 \%$ pure), Tebuconazol (CAS-No:107534-96-3, PESTANAL ${ }^{\circledR}, 99,3 \%$ pure). Acetone (CAS: 67-64-1, Fisher Chemical, HPLC solvent) was purchased from Fisher Scientific (IIlkirch, France). Scintillation liquid (Flo-Scint II ${ }^{\mathrm{TM}}$ ) was purchased from Perkin Elmer (Waltham, Massachusetts, USA).

\subsection{Animal care}

Fish were purchased from the fish farming Carpio (Consac, France) in the size range 10-12 cm. They were first acclimatized for two weeks in opaque tanks under controlled conditions $\left(18^{\circ} \mathrm{C}\right.$ with a $12: 12 \mathrm{~h}$ light regime). Water was aerated and dechlorinated prior to fish introduction. Half of the water was renewed every day and fish were fed daily with commercial pellets. No mortality occurred during the acclimation period. Experimental procedures were conducted under French animal handler's certificate $n^{\circ} .31-103$, giving authorization to experiment on living vertebrates.

\subsection{Experimental design}

Fish were exposed to a pesticide mixture and/or temperature increased to obtain four conditions: the CONTROL group (fish at $22{ }^{\circ} \mathrm{C}$ non-exposed to pesticides), the TEMP group (fish at $32{ }^{\circ} \mathrm{C}$ non-exposed to pesticides), the PEST group (fish exposed to pesticides at $22^{\circ} \mathrm{C}$ ) and the PEST*TEMP groups (fish exposed to pesticides at $32{ }^{\circ} \mathrm{C}$ ) as previously described (Gandar et al., 2017). Goldfish were placed in $60 \mathrm{~L}$ opaque aquaria in a temperature controlled room $\left(22^{\circ} \mathrm{C}, 12\right.$ fish per aquarium and 2 aquaria per condition*exposure time). Prior to pesticide exposure, the water of the TEMP and PEST*TEMP groups was gradually heated $\left(1^{\circ} \mathrm{C} /\right.$ day $)$ to reach $32{ }^{\circ} \mathrm{C}$. Fish were then exposed for $6 \mathrm{~h}, 96 \mathrm{~h}$ or $16 \mathrm{~d}$ to the mixture of pesticides. Water was renewed by half every day. Temperature, $\mathrm{pH}$, oxygenation and conductivity were assessed $1 \mathrm{~h}$ after the water renewal (Supplementary Table 2). Ammonium, nitrites and nitrates concentrations were measured by colorimetry at each time of exposure (Supplementary Table 2). Fish were fed daily and no mortality occurred during exposures.

Twelve fish per condition were randomly sampled at $6 \mathrm{~h}, 96 \mathrm{~h}$ and $16 \mathrm{~d}$. Fish were euthanized with an overdose of benzocaine. Blood samples were collected from the caudal vein by puncturing using a heparinized syringe and centrifuged. Plasma samples were kept at $-80^{\circ} \mathrm{C}$. Fish were weighted (to the nearest $10 \mathrm{mg}$ ) and measured (fork length to the nearest $\mathrm{mm}$ ). Livers and white muscles were collected, weighted (to the nearest $0.1 \mathrm{mg}$ ), frozen in liquid nitrogen and kept at $-80^{\circ} \mathrm{C}$.

\subsection{Plasma cortisol concentration}

Plasma cortisol concentration was assessed by radioimmunoassay (RIA) as previously described (Désautés et al., 1997). The plasma cortisol concentration was expressed in ng. $\mathrm{mL}^{-1}$. 


\subsubsection{Metabolite extraction}

Metabolites were extracted from $50 \mathrm{mg}$ tissue samples with a methanol/chloroform/water (2.0:2.0:1.8) solvent mixture using a Twostep protocol adapted from Lin et al. (2007) and Wu et al. (2008) with slight modifications. Briefly, livers of fish were ground and weighted. A $50 \mathrm{mg}$ sample was homogenized using a Fastprep ${ }^{\circledR}$ homogenizer with methanol $\left(4 \mathrm{~mL} \cdot \mathrm{g}^{-1}\right)$ and Milli-Q water $\left(0.85 \mathrm{~mL} \cdot \mathrm{g}^{-1}\right)$ and vortexed for $5 \mathrm{~s}$. Samples were then mixed with chloroform $\left(4 \mathrm{~mL} \cdot \mathrm{g}^{-1}\right)$ and Milli-Q water $\left(2 \mathrm{~mL} \cdot \mathrm{g}^{-1}\right)$ and vortexed during $5 \mathrm{~s}$, incubated $15 \mathrm{~min}$ at $4{ }^{\circ} \mathrm{C}$ and then centrifuged at $2800 \mathrm{~g}$ for $15 \mathrm{~min}$. The entire upper layer was collected and kept at $-20^{\circ} \mathrm{C}$.

\subsection{2. $1 \mathrm{D}-{ }^{1} \mathrm{H}$ NMR spectroscopy and spectral preprocessing}

Samples were evaporated using a SpeedVac and resuspended in a phosphate buffer (pH 7.4) prepared in a deuterated water $\left(\mathrm{D}_{2} \mathrm{O}\right)$ and containing $1 \mathrm{mM}$ of sodium 3-trimethylsilyl-2,2,3,3-- $\mathrm{d}_{4}$-propionate (TMSP, internal chemical shift standard). Samples were centrifuged and $600 \mu \mathrm{l}$ of supernatant were transferred in 5 mm NMR tubes. NMR Spectra were acquired at $600 \mathrm{MHz}$ with a Bruker Avance spectrometer (Bruker, Karlruhe, Germany) with a SampleJet autosampler using a NOESY 1D sequence to remove the water signal. For 1D spectra, 256 scans were collected into 64,000 data points with a relaxation delay of $2 \mathrm{~s}$. The free induction decays (FID) were Fourier transformed and spectra were phased, baseline corrected and calibrated (TMSP, $\delta 0$ ppm) using TOPSPIN v2.1 software (Bruker, Karlsruhe, Germany). A variable size bucketing was used and 102 buckets were selected according to resonance signals and multiplicity between 9.4 and 0.5 ppm, excluding residual water signal. The signal intensity in each bucket was integrated using AMIX software (version 3.9.13, Bruker, Karlsruhe, Germany). Data were normalized with respect to the total spectrum intensity using meancentering and Pareto scaling to allow comparison between samples.

\subsubsection{Statistical analysis}

Supervised Partial Least Square-Discriminant Analysis (PLS-DA) was used to assess the discrimination between groups. OSC filter was applied prior to the analysis to remove the analytical and biological variations that were not related to group discrimination (Beckwith-Hall et al., 2002). $Q^{2}$ (predictability of the model, threshold of 0.4 ) and $R^{2}$ (total explained variations) values were used to confirm the validity of the models. Permutation tests (200 iterations) were then applied to assess PLS-DA model robustness. The Variable Importance in Projection (VIP, weight of variables for each component; value > 1.0 - arbitrary threshold) was used to determine discriminant buckets. Comparisons between conditions were performed using KruskalWallis tests and post-hoc tests (significance threshold $=0.05$ ).

SIMCA P and R softwares were used respectively for PLS-DA analysis and Kruskal-Wallis test. 

$15,900 \mathrm{M}^{-1} \mathrm{~cm}^{-1}$ was used. to Verslycke et al. (2004):

The discriminant metabolites were identified using the literature, home-made and freeware databases such as the Biological Magnetic Resonance Data Bank (www.bmrb.wisc.edu/) (Ulrich et al., 2008) and the Human Metabolome Database (www.hmdb.ca/) (Wishart et al., 2007). To confirm the chemical structure of metabolites of interest, 2D ${ }^{1} \mathrm{H}-{ }^{1} \mathrm{H}$ COSY (Correlation Spectroscopy) and $2 \mathrm{D}^{1} \mathrm{H}^{13}{ }^{13} \mathrm{C} \mathrm{HSQC}$ 5Heteronuclear Single Quantum Coherence Spectrosocpy) NMR experiments were performed on selected samples. The spectral assignment was based on matching $1 \mathrm{D}$ and $2 \mathrm{D}$ data to reference spectra.

\subsection{Energy reserves and cellular energy allocation}

Energetic reserves at the molecular and cellular level are essential to sustain the stress responses of fish. Total carbohydrate, lipid and protein contents and oxygen consumption rate in the electron transport system (ETS) were measured in liver and white muscle of fish with protocols adapted from De Coen and Janssen (1997). Carbohydrate concentration ( $\mu \mathrm{g} \cdot \mathrm{mg}^{-1}$ of tissue) was quantified using a microplate spectrophotometer at $492 \mathrm{~nm}$ against glucose in TCA. Protein concentration ( $\mu \mathrm{g} \cdot \mathrm{mg}^{-1}$ of tissue) was quantified by adding Bradford reagent and reading absortion at $595 \mathrm{~nm}$ against bovine serum albumin in 0,2 N NaOH (Bradford, 1976). Total lipid concentration ( $\mu \mathrm{g} \cdot \mathrm{mg}^{-1}$ of tissue) was measured by reading absorption at $525 \mathrm{~nm}$ against tripalmitin in chloroform. The ETS activity $\left(\mathrm{mJ}_{\mathrm{mg}} \mathrm{mg}^{-1}\right.$ tissue. $\left.\mathrm{h}^{-1}\right)$, was measured by absorbance reading at $490 \mathrm{~nm}$ when iodonitrotetrazolium (INT) was added and during $3 \mathrm{~min}$. The molar extinction coefficient of

Carbohydrate, protein and lipid concentrations were transformed in their energetic values $\left(\mathrm{mJ}^{\mathrm{mg}} \mathrm{mg}^{-1}\right.$ of tissue) using their enthalpy of combustion (17, 24 and $39.5 \mathrm{~kJ}^{-g^{-1}}$ respectively). Available energy (AE), energy consumption (EC) and cellular energy allocation (CEA) in liver and white muscle were then calculated according

$$
\begin{gathered}
\mathrm{AE}=\text { carbohydrates }+ \text { proteins }+ \text { lipids }\left(\mathrm{mJ}_{\mathrm{mg}} \mathrm{mg}^{-1} \text { tissue }\right) \\
\mathrm{EC}=\text { ETS activity }\left(\mathrm{mJ} \cdot \mathrm{mg} \text { tissue } \mathrm{e}^{-1} \cdot \mathrm{h}^{-1}\right) \\
\mathrm{CEA}=\frac{\mathrm{AE}}{\mathrm{EC}}\left(\mathrm{h}^{-1}\right)
\end{gathered}
$$

\subsection{Antioxidant and detoxification enzymes}

The antioxidant system is a central component of the defense system against chemical and thermal stressors. The activities of the SOD, CAT and GST were measured in the liver of fish by spectrophotometry. Protocols were adapted from Feirrera et al. (2015). Briefly, tissue $(50 \mathrm{mg})$ was homogenized at $4{ }^{\circ} \mathrm{C}$ using a FastPrep $^{\circledR}$ in K-phosphate buffer $(1 \mathrm{~mL}, 0.1 \mathrm{M} \mathrm{pH}$ 7.8; $100 \mathrm{mM} \mathrm{K-phosphate,} \mathrm{20 \%} \mathrm{(v/v)} \mathrm{glycerol} \mathrm{and} 0.2 \mathrm{mM}$ fluoride phenylmethylsulphonyl). Homogenates were centrifuged at $10,000 \mathrm{~g}$ for $15 \mathrm{~min}$ at $4{ }^{\circ} \mathrm{C}$. Supernatants 
(post-mitochondrial fraction, PMS) were distributed in 4 volumes of $100 \mathrm{~mL}$ and stored at $-80{ }^{\circ} \mathrm{C}$ for two weeks.

Protein concentrations were determined with the Bradford method. CAT activity was determined at $240 \mathrm{~nm}$ by measuring the breakdown of $\mathrm{H}_{2} \mathrm{O}_{2}$ (Babo and Vasseur, 1992). SOD activity was measured at $340 \mathrm{~nm}$ for 5 minutes against standard SOD (Paoletti et al., 1986). GST activity was assessed at $340 \mathrm{~nm}$ for $5 \mathrm{~min}$ by measuring the conjugation between 1-chloro- 2,4-dinitrobenzene and reduced glutathione (Habig et al., 1974). The enzyme activity was expressed in units per mg of proteins (U.mg ${ }^{-1}$ ).

\subsection{Somatic and condition indexes}

\subsection{Statistical analyses}

Except for the metabolomics data, differences between groups were analyzed with ANOVA software and LSD post-hoc tests after validation of the assumption of homogenous variances with Levene test. Canonical analyses were used to integrate data from plasma cortisol concentration, AE and CE in liver and muscle, somatic indexes (HSI and MI) and condition factor (FCF) of fish. The distance between groups was calculated for each time of exposure with the Mahalanobis distance, and the obtained p-value was used to determine significant separation with a threshold of 0.05 .

\section{Results}

\subsection{Endocrine, metabolic and physiological responses}

The direction and significance of the endocrine, metabolic and physiological responses of fish to individual and combined chemical and thermal stresses are presented in Table 4. The mean values for all parameters are 
listed in the supplementary Table 3. Compared to the CONTROL group, PEST exposure significantly increased plasma cortisol at T6 $\mathrm{h}$, hepatic carbohydrates at T6 $\mathrm{h}$ and T16 d, hepatic proteins at T6 $\mathrm{h}$, liver EC at T6 h, 231 lipids and AE in muscle at T96 $\mathrm{h}$ and HSI at T6 $\mathrm{h}$ and T16 d. A decrease was found in liver lipids. At T6 $\mathrm{h}$, the 232 TEMP group showed increases in cortisol, hepatic protein concentration and EC in liver and white muscle. A 233 decrease was observed in muscle AE and CEA. No effects were found at T96 h and T16 d (Table 4, Table S3).

234 The PEST*TEMP group showed an increase of plasma cortisol at $\mathrm{T} 6 \mathrm{~h}$ compared to CONTROL, but the concentration was similar to that observed in both individual stress groups (Supplementary Table 3). There was no other effect compared to CONTROL at T6h. On the opposite, PEST*TEMP significantly increased muscle lipids, AE and CEA, HSI and MI at T16d. A significant decrease in the FCF was observed at T16d. PEST*TEMP also tended to decrease the plasma cortisol concentration compared to CONTROL group at T16d $(p=0.053$, LSD post-hoc test).

Plasma cortisol concentration, liver and muscle $\mathrm{AE}$ and $\mathrm{CE}$, somatic indexes ( $\mathrm{HSI}$ and $\mathrm{MI}$ ) and condition factor (FCF) of fish were integrated in canonical analyses associated to Mahalanobis distance computation to measure the separation between groups. Canonical representations for each exposure time and Mahalanobis distances between CONTROL and stressed groups were shown in the Fig. 1. Results showed a stress-specific and time-dependent response of fish with an opposite trend between individual and combined stress effects. The canonical analysis and Mahalanobis distances showed a significant separation between the CONTROL group and both the TEMP and PEST groups at T6 $h$ (Fig. 1A), but not at T96 $h$ and T16 d (Fig. $1 B$ and C respectively). On the opposite, the distance between the PEST*TEMP and the CONTROL groups was nonsignificant after $6 \mathrm{~h}$ but increased over time to become significant after $16 \mathrm{~d}$.

\section{2. ${ }^{1} \mathrm{H}-\mathrm{NMR}$ metabolomic analysis}

Representative $600 \mathrm{MHz}{ }^{1} \mathrm{H}$ NMR spectra of control and exposed goldfish obtained from aqueous extracts of liver tissues at time-point 16 days were shown in Supplementary Fig. 1. Primary metabolites have been annotated in the spectra. OSC-PLS-DA score plots obtained for each exposure duration are shown in Fig. 2.

At $\mathrm{T} 6 \mathrm{~h}$, a valid and robust model ( $\mathrm{A}=3$ latent component, $\mathrm{R} 2=52.7 \%, \mathrm{Q} 2=0.37$ ) has been built for the integrated spectra: the score plot of the PLS-DA (Fig. 2A) showed a clear separation between the group of fishes at $22{ }^{\circ} \mathrm{C}$ and the group of fishes at $32{ }^{\circ} \mathrm{C}$, regardless pesticides exposure.

36 buckets had a VIP value $>1.0$ and was statistically different by the Kruskal-Wallis test. These differences corresponded to 12 metabolites, according to 2D NMR spectra annotation. High temperature (TEMP) increased glutamine, reduced glutathione, phosphorylcholine, taurine, and decreased UDP and UTP compared to CONTROL group. The PEST*TEMP and the TEMP groups were not clearly separated on the OSCPLS-DA score plot (Fig. 2A). However, PEST*TEMP exposure significantly decreased proline, UDP and UTP levels 
compared to control fish, and PEST exposure significantly increased glutamine, reduced glutathione, succinate, choline, AMP, NAD+ and decreased maltose level compared to control fish (Table 1 and Fig. 2D).

At T96 $\mathrm{h}$, the score plot of the PLS-DA showed a clear separation between the $22{ }^{\circ} \mathrm{C}$ group and the 32 ${ }^{\circ} \mathrm{C}$ group along the first latent component, and between the exposed fish and the non-exposed fish for the 32 ${ }^{\circ} \mathrm{C}$ group (Fig. 2B). This analysis generated a PLS-DA model with three latent components, with R2Y $=54.3 \%$ and $Q_{2}=0.34$. Thirty buckets were identified as discriminant in the metabolic profiles, corresponding to 8 metabolites. Despite close metabolic fingerprints for these two groups, PEST exposure significantly decreased AMP compared to CONTROL. In the TEMP group, significant increase was observed for maltose, while proline, malonate, AMP, NAD+, UDP and UTP decreased. PEST*TEMP exposure significantly decreased proline, succinate, AMP, NAD+, UDP and UTP (Table 2 and Fig. 2E).

At T16 d, same patterns were observed in the score plot (Fig. 2C) but difference between exposed and non-exposed fishes at $32{ }^{\circ} \mathrm{C}$ was more pronounced. 15 metabolites were found significant between at least two groups. As compared to CONTROL, decreases were found in isoleucine, leucine, valine, alanine, proline, lysine, glutamine, creatine, taurine, lactate, AMP, NAD+ and increases were found in maltose for the PEST*TEMP group. TEMP condition increased significantly reduced glutathione and phosphorylcholine, and decreased proline compared to CONTROL. No discriminant metabolites were found for PEST exposure (Table 3 and Fig. 2F).

\subsection{Defense system induction}

SOD, CAT and GST activities were measured in the liver of fish (Fig. 3). An increase of CAT activity was observed in the PEST group at T6 $\mathrm{h}$. CAT and SOD activity decreased in the PEST*TEMP group at T96 $\mathrm{h}$ and then increased at T16 $\mathrm{d}$. GST activity tended to increase in the PEST group at T6 $\mathrm{h}$ compared to the CONTROL and was significantly higher than in the PEST*TEMP group. No effects were observed at T96 $h$ and T16 $d$. The TEMP group showed no response of these enzyme activities.

\section{Discussion}

The aim of this study was to assess the adaptive response of goldfish submitted to individual and combined chemical and thermal stress. We first characterized the primary endocrine stress response (plasma cortisol), then secondary responses (hepatic induction of enzymatic defense systems and metabolic responses in liver and white muscles) and tertiary responses (global condition of fish). We found stress-specific and timedependent responses of goldfish at all biological levels observed. Multivariate analyses showed two contrasting patterns of response (1) Fish exposed to single chemical or thermal stressors had a significant stress response at T6 $\mathrm{h}$ followed by a recovery at T96 $\mathrm{h}$ and T16 $\mathrm{d}$ from the molecular to the individual levels (significant stress response and low deleterious effects across biological levels). In contrast, (2) fish exposed to 
ACCEPTED MANIUSCRIPT

combined chemical and thermal stressors had no stress response at $\mathrm{T} 6 \mathrm{~h}$, followed by important deleterious changes at T16 $\mathrm{d}$ from the molecular to the individual levels (absence of stress response and high deleterious effects across biological levels).

4.1 Responses to individual stress (PEST and TEMP groups): an adapted and coordinated early response.

\subsubsection{Cortisol response to single stressors}

In fish exposed to single stressors, we found an increase of plasma cortisol concentration at T6h in all stressed groups compared to the CONTROL groups. Several studies have shown an increase in plasma cortisol in fish exposed to herbicides (Waring and Moore, 2004; Soso et al., 2007), fungicides (Hashim and Zaki, 2005; Tierney et al., 2006) or temperature increase (Lyytikäinen et al., 2002; Fernandino et al., 2013). Our results show that both pesticide mixture and temperature increase triggers an endocrine stress response, showing that fish have initiated a general stress response. It was associated to the induction of a number of antioxidant defense systems, depending on the nature of the stress. For instance we observed an increase in CAT and GST activities, glutathione, and glutamine - on which glutathione synthesis depends - and taurine.

\subsubsection{Antioxydant response to single stressors}

CAT and SOD catalyze the reduction of ROS, participating to their detoxification (Regoli et al., 2011; Regoli and Giuliani, 2014). In another hand, GST intervenes in the detoxification of both ROS and lipophilic chemicals, such as pesticides, by catalyzing their conjugation with glutathione. Induction of CAT, SOD and/or GST are consistent with results of previous studies in fish exposed to herbicides (Jin et al., 2010; Guilherme et al., 2012; Stara et al., 2012; Xing et al., 2012; Blahová et al., 2013; Nwani et al., 2013; Sinhorin et al., 2014) and high temperature (Gorbi et al., 2005; Madeira et al., 2013; Yin et al., 2013). We observed a transient increase activity of CAT and GST in the PEST group at T6 $\mathrm{h}$, suggesting an increase in ROS production under the pesticide exposure, although SOD activity remained at the control level. GST activity increased also suggesting an induction of the hepatic detoxification process. In contrast, no responses of CAT, SOD and GST activity were observed in the TEMP group, despite the fact that temperature increase is a well-known pro-oxidant factor in ectothermic species (Cui et al, 2014).

Glutathione is a well-known ROS scavenger and was used as a biomarker of oxidative stress in many studies (Regoli et al., 2011). Glutathione synthesis depends on the cellular concentration of glutamate and glutamine (DeBerardinis and Cheng, 2010). NMR analysis showed an increase of these molecules at T6 $\mathrm{h}$ in both the PEST and TEMP groups. Considering their extensive variety of critical roles in cell function and antioxidant defenses, the increase of glutamine in the liver of fish can be considered as an important response to both chemical and thermal stressors.

Thermal stressor also increased hepatic taurine levels at T6 $h$ and decreased malonate at T96 $h$. Taurine is a sulfur-amino acid which counteracts oxidative stress, although specific mechanisms are poorly 
A CCEPTED MANTSCR TP

understood (Kumar et al., 2009; Rosemberg et al., 2010). On the opposite, malonate induces mitochondrial

potential collapse and ROS production, leading to cell death (Fernandez-Gomez et al., 2005). Consequently, increased taurine level and decreased malonate may act in the same way to prevent ROS induced damages in thermal exposed fish.

An increase in phospholipid precursor concentrations (choline and derivative) in both groups may also be a response to lipid peroxidation caused by oxidative stress and requiring the synthesis of novel phospholipids (Li et al., 2014; Xu et al., 2015).

\subsubsection{Metabolic response to single stressors}

At the same time, an increase in energy consumption is observed in the liver - increased liver energy consumption (EC) at T6 $\mathrm{h}$ in both the PEST and TEMP groups - and, for the TEMP group, in the muscle. The increase in basal metabolism is classic in fish subjected to stress and corresponds to the bioenergetic cost of the induction of systems of protection, detoxification and repair of damage. Increased ETS activity was shown in ectotherm species in response to chemical exposure and temperature increase (Gagné et al., 2006, 2007; Sappal et al., 2015; Schmidlin et al., 2015), which is consistent with our results. ETS activity reflects the production of ATP by mitochondria which depends directly on the cellular energy demand (Gagné et al., 2007; Smith et al., 2012). The induction of defense systems, including detoxification, protection and reparation processes, is a costly process which increases the cellular energy demand and requires metabolic compensations (Sherwood et al., 2000; Trudel et al., 2010; Sokolova et al., 2012). Proteins are the most costly energy molecules to synthesize (Jorgensen, 1988; Smith et al., 2001). Increased hepatic protein concentrations were observed at T6 $\mathrm{h}$ in both the PEST and TEMP exposed fish. These increases may reflect the induction of defense systems, including antioxidant enzymes or heat shock proteins (Viant et al., 2003). Increased bioenergetic cost due to defense protein induction was shown in fish exposed to heat shock (Viant et al., 2003) or pollutants (Smith et al., 2001). We can also note that protein concentrations increased at T6 $\mathrm{h}$ but not at T96 $\mathrm{h}$ or T16 d, which is consistent with the induction of antioxidant defenses and the increased energy consumed. In PEST exposed fish, the co-occurring increases observed at T6 $\mathrm{h}$ in liver EC, AMP and succinate, an intermediary product of the TCA cycle, showed a metabolic compensation to the increased energy requirement. In a consistent way, hepatic glucose and lipids, which are important substrates for the energy production pathways, showed important decreases at T6 $\mathrm{h}$. However, we found an increase in total carbohydrate concentration in liver at T6 $\mathrm{h}$ and T16 d. Glycogen is the common form of storage of carbohydrates in cells and increased glycogen deposition is a classic metabolic response to cortisol (Mommsen et al., 1999). Maltose was also significantly decreased in livers after $6 \mathrm{~h}$ of pesticides exposure. Maltose as a disaccharide could yield two monosaccharides of glucose upon hydrolysis. Maltose degradation could serve as an energy supplement to replenish pesticides induced energy demand (Li et al., 2017). In the TEMP group, energy consumption increased at T6 $\mathrm{h}$ both in liver and white muscle, associated with significant decreases in muscular AE and CEA. In the tolerance range, a higher temperature affects biochemical kinetics and enzyme 
activity leading to basal and active metabolism increased (Cech et al., 1985; López-Olmeda and SánchezVázquez, 2011; Manciocco et al., 2014). The increased energy consumption observed in liver and muscle at T6 $\mathrm{h}$, and the decreased available energy in muscle are consistent with systemic metabolic acceleration under higher temperature. The drop observed at T6 $\mathrm{h}$ in the muscle CEA reflected a decreased metabolic status. Inversely, the hepatic CEA remained constant despite the increased energy consumption. A similar dichotomy between muscular and hepatic metabolic responses to heat shock was observed in Oncorhynchus mykiss (Viant et al., 2003). Under stress, lipid and protein reserves in white muscles are released into the blood system, carried to the liver and used as substrates for gluconeogenesis and protein synthesis (Mommsen et al., 1999). These results show that higher temperature induce an increased energy demand and metabolic compensation through the whole organism. The vast majority of metabolic responses to higher temperature disappeared at T96 $\mathrm{h}$ and T16 d, suggesting that thermal exposed fish reached an adapted physiological status. So, with increased temperatures, the increase in metabolism is also directly related to the effect of temperature on the enzymatic activity and kinetics of biochemical reactions. This energy cost is supported by an increase in ATP production by ETS as well as glycolysis, Krebs cycle and gluconeogenesis from liver and / or muscle proteins or lipids.

\subsubsection{Physiological response to single stressors}

Finally, the lack of effect on the general condition of the fish and the disappearance of most of these responses at the end of the experiment suggest that the fish have an effective response to achieve a more appropriate physiological state. However, some effects persist at T16 $d$ in the liver of the PEST group, especially for the HSI that increase at T6 $h$ and T16 d. HSI increase was shown in fish exposed to pesticides (Arnold et al., 1995; Biagianti-Risbourg and Bastide, 1995; Bacchetta et al., 2014). HSI is correlated to the metabolic status of the liver, and may reflect increased glycogen storage (Chellappa et al., 1995; Zheng et al., 2013). But a swollen HSI may also be due to sequestration of lipophilic pollutants in lipid droplets (BiagiantiRisbourg and Bastide, 1995), increased detoxification capacities (Arnold et al., 1995; Bacchetta et al., 2014) or degenerative changes in the liver tissue (Arnold et al., 1995; Guardiola et al., 2014). Histopathological analyzes could determine whether this effect is indicative of histological damage caused by pesticides, increased liver detoxification capacities or pesticide trapping in lipid vacuoles. We can therefore conclude that pesticide exposure induced an increased energy demand in the liver of the goldfish, probably due to defense system induction, and metabolic compensations. While other responses shut down, the increased HSI, MI and hepatic carbohydrate concentration observed at T16 d indicated persisting metabolic and/or histological perturbations in goldfish exposed to the pesticide mixture. However, compared to fish exposed to combined stressors, fish exposed to single stressors had lower deleterious effects of treatments at the individual level.

To summarize, fish exposed to single stressors displayed a significant cortisol response with coordinated effects on the metabolism and energetic reserves and low deleterious effects at different time scales. These results are consistent with a metabolic compensation strategy, i.e. the set-up of a coordinated 
stress responses and metabolic responses with a depletion of energetic reserves to maintain homeostasis and limit the deleterious effects of single stressors (Sokolova et al., 2013). However, it is not clear yet whether fish can implement such coordinated stress response when exposed to a combination of stressors that may have synergistic or antagonistic effects.

4.2 Responses to combined stressors (PEST * TEMP group): an inhibited early response and significant effects from the molecular to the individual scale at T16 d.

\subsubsection{Cortisol response to combined stressors}

Cortisol level in fish subjected to both an increase in temperature, and pesticides mixture increased at T6 h. Surprisingly, combined stressors did not lead to an additional increase in cortisol secretion. This result shows that fish under thermal stress does not respond to pesticide exposure by an increase in cortisol secretion. First, a possible explanation is that pesticide mixture toxicity decreases with the increase in temperature. However, the vast majority of studies on aquatic vertebrates showed an opposite effect (Gluth and Hanke, 1984; Ferrando et al., 1987; Osterauer and Köhler, 2008; Rohr and Palmer, 2013). Second, the exposure to a first stressor may affect the normal function of the HPI axis and prevent the induction of a stress response to a subsequent stressor (Romero, 2004; Auperin and Geslin, 2008). In this last case, the hyporesponsive HPI axis to a consecutive stressor could shut down the fish ability to perform an appropriate stress response (Romero, 2004, 2010).

It is also interesting to note that cortisol concentration tended to decrease in the PEST*TEMP group compared to controls after 16 days of pesticide exposure ( $p=0.053$, LSD post-hoc test). A lower level of cortisol is generally observed in organisms submitted to an extreme stress (Romero, 2004, 2010). This decrease could be due to pesticide induced endocrine perturbation of the HPI axis function. Studies have shown that fish exposed to chronic chemical stressors such as pesticides display a decreased corticosteroid response to a second (Cericato et al., 2008, 2009; Bisson and Hontela, 2002; Nascimento et al., 2012; Koakoski et al., 2014). This inhibition could be linked to a toxic effect of pesticides, including tebuconazole, on interrenal cells or a regulation of the activity of the HPI axis at the level of the hypothalamus or pituitary (Koakoski et al., 2014; Zhang et al. 2015). Endocrine disruption of the synthesis of steroid hormones, i.e. cortisol and/or sex hormones can have important consequences on the fitness and survival of fish, affecting physiological traits and behaviors associated with stress adaptation and reproduction (Ankley et al., 2002).

\subsubsection{Antioxydant responses to combined stressors}

Surprisingly, all defense systems and metabolic responses observed in response to individual stresses were inhibited in fish exposed to multiple stressors at early time. The PEST*TEMP exposed fish showed no response of CAT, GST, glutathione, glutamine, taurine, choline and phosphorylcholine at T6 h. Moreover, CAT and SOD activities were reduced compared to control fish at T96 h. Similar patterns of reciprocal inactivation of defense systems were shown in Pimephales promelas exposed to copper and heat shock (Lapointe et al., 
2011). Moreover, it is well established that ROS (e.g. superoxide) oxidizes non enzymatic antioxidant defenses and inactivates several enzymes including CAT (see a review in Valavanidis et al., 2006). Inhibition of the stress defenses may indicate an overproduction of ROS under combined chemical and thermal stresses which exceeded the antioxidant capacity of the cells. Inhibition of defense system reflects an antagonistic effect of thermal and chemical stressors on the overall stress response. Interestingly, CAT and SOD activity increased significantly at T16 d while other responses were still shut down. This delayed response emphasizes the adverse effect of chemical and thermal induced oxidative stress on cellular components, with increased risk of cell and tissue injuries.

\subsubsection{Metabolic responses to combined stressors}

At the molecular level, a decrease in the concentration of a large number of metabolites indicates a significant disturbance of amino acid metabolism, energy production and defense against oxidative stress. In the PEST*TEMP group, the metabolic responses to individual stressors measured at T6 $\mathrm{h}$ disappeared, including the responses observed at the molecular, cellular and tissue levels. In particular, the ETS activity in both liver and muscle decreased compared to the PEST and TEMP groups. The decreased ETS activity under combined stressors could result from (1) perturbations in the normal function of the ETS or (2) a decreased mitochondrial densities in cells (Lannig et al., 2006; Sokolova and Lannig, 2008; Lavergne et al., 2015). In ectothermic species, mitochondrial plasticity plays a critical role in the metabolic response to environmental stressors (Strobel et al., 2013). The incapacity of fish to maintain an elevated energy production under multiple stress exposures could explain the absence of induction of the defense system observed at T6 $h$. Consequently, it could potentiate oxidative damages on cellular components, including proteins. The creatine phosphocreatine system plays a critical role in cellular energy metabolism (Sun et al., 2012; Wang et al., 2017). Thus, the decreased creatine, found under combined exposure stressors at T16 d strengthens the perturbation of energy metabolism which is consistent with the above conclusion.

PEST*TEMP exposed fish showed significant decreases in amino-acids levels as soon as T6 $h$, with reduced levels of proline and lysine. At T16 d, reduced concentrations were found for isoleucine, leucine, valine, alanine, proline, lysine, glutamate, glutamine, creatine and taurine, indicating an important perturbation of amino-acid metabolism and/or oxidative damages on proteins.

\subsubsection{Physiological responses to combined stressors}

At the tissue level, the increase in HSI and the deposition of lipids in the muscles also indicate disturbances in energy metabolism, sequestration of pesticides in lipid vacuoles and / or tissue damage. Finally, a significant decrease in the overall condition of the fish (FCF) is visible at T16 $\mathrm{d}$. When fish are subjected to both combined stressors, the general stress response is inhibited, at least initially, with significant individual-level effects on overall fish health. Given that the stress response is fundamental in enabling organisms to acclimate to changes in their environment, its inhibition under multiple stressors seems to have 
important consequences on fitness and fish performance affecting physiological traits and behavioral responses related to stress adaptation and reproduction (Pankhurst and Van Der Kraak, 2011).

\section{Conclusion}

Taken together, these results indicate that (1) single thermal and chemical stressors lead to a general stress response and a metabolic compensation strategy, i.e. the set-up of a coordinated stress response and depletion of energetic reserves limiting adverse effects at higher biological levels. The lack of effect on the general condition of the fish (i.e. tertiary response) suggests that the stress response set up is adapted and effective. However, (2) the patterns of metabolic response and defensive systems strongly depended on the nature of the stress (thermal vs. chemical). Finally, (3) fish were unable to establish an effective stress response when chemical and thermal stressors were combined, with deleterious effects at the individual level. Exposure to combined chemical and thermal stressors disrupts the stress response and results in a decrease in the overall condition of the fish, indicating a synergistic effect of temperature and pesticide mixture on goldfish. These results also outline the central role of metabolism in these stress responses. The decrease in cellular energy metabolism when the two stresses are combined is consistent with the shift from a compensation strategy to a metabolic conservation strategy (Sokolova et al., 2013). In other words, exposure to a combination of stressors might exceed the metabolic capacity of the fish, leading to an early inhibition of the stress response (lower level of cortisol, antioxydant defenses, and lower depletion of energy reserves) with potential high deleterious effects at the individual level.

To our knowledge this study is the first to evaluate the combined effects on the fish stress response of temperature warming and water contamination by pesticide mixtures with an integrated molecule- individual scale. The combined analysis of omic approaches, here metabolomics, and more conventional biochemical approaches seems to be a powerful way to evaluate the response of organisms undergoing multiple stresses. Future studies should now consider different combinations of stressors and evaluate their effects on individuals across biological levels, from the molecules to the whole individual, while taking into account the inter-individual variability of sensitivity. Because global changes are exposing organisms to a combination of stressors at the same time, this will help understanding and predicting the responses of natural populations to actual and future stresses.

\section{Acknowledgments}

The authors wish to thank Dr Lisa Jacquin for helpful comments and corrections on an earlier draft. This work has been carried out as a part of "ADAPT'EAU" (ANR-11-CEPL-008), a project supported by the French National Research Agency (ANR) within the framework of "The Global Environmental Changes and 


\section{ACCEPT'TD MANISCRTP'T}

Societies (GEC\&S) program". AG was supported by a doctoral grant of the French Ministry of Higher Education and Research. The authors confirm no conflict of interest.

\section{References}

Alim'agri, 2012. Agriculture, Agri-food and Forest data. French Ministry of Agriculture, Agro-food and Forest report. [WWW Document]. URL http://agriculture.gouv.fr/ministere/alimagri-chiffres-cles-2012

Ankley, G.T., Kahl, M.D., Jensen, K.M., Hornung, M.W., Korte, J.J., Makynen, E.A., Leino, R.L., 2002. Evaluation of the Aromatase Inhibitor Fadrozole in a Short-Term Reproduction Assay with the Fathead Minnow (Pimephales promelas). Toxicol. Sci. 67, 121-130. doi:10.1093/toxsci/67.1.121

Arnold, H., Pluta, H.-J., Braunbeck, T., 1995. Simultaneous exposure of fish to endosulfan and disulfoton in vivo: ultrastructural, stereological and biochemical reactions in hepatocytes of male rainbow trout (Oncorhynchus mykiss). Aquat. Toxicol. 33, 17-43. doi:10.1016/0166-445X(95)00006-P

Auperin, B., Geslin, M., 2008. Plasma cortisol response to stress in juvenile rainbow trout is influenced by their life history during early development and by egg cortisol content. Gen. Comp. Endocrinol. 158, 234239. doi:10.1016/j.ygcen.2008.07.002

Babo, S., Vasseur, P., 1992. In vitro effects of Thiram on liver antioxidant enzyme activities of rainbow trout (Oncorhynchus mykiss). Aquat. Toxicol. 22, 61-68. doi:http://dx.doi.org/10.1016/0166-445X(92)90036-M

Bacchetta, C., Rossi, A., Ale, A., Campana, M., Parma, M.J., Cazenave, J., 2014. Combined toxicological effects of pesticides: A fish multi-biomarker approach. Ecol. Indic. 36, 532-538. doi:10.1016/j.ecolind.2013.09.016

Barton, B.A., 2002. Stress in fishes: a diversity of responses with particular reference to changes in circulating corticosteroids. Integr. Comp. Biol. 42, 517-525. doi:10.1093/icb/42.3.517

Baudiffier, D., 2012. Modes de perturbation de la stéroïdogenèse testiculaire et de la spermatogenèse chez le poisson zèbre (Danio rerio) par des fongicides azolés. Université Rennes 1.

Beckwith-Hall, B.M., Brindle, J.T., Barton, R.H., Coen, M., Holmes, E., Nicholson, J.K., Antti, H., 2002. Application of orthogonal signal correction to minimise the effects of physical and biological variation in high resolution ${ }^{1}$ H NMR spectra of biofluids. Analyst 127, 1283-1288. doi:10.1039/b205128c

Biagianti-Risbourg, S., Bastide, J., 1995. Hepatic perturbations induced by a herbicide (atrazine) in juvenile grey mullet Liza ramada (Mugilidae, Teleostei): an ultrastructural study. Aquat. Toxicol. 31, 217-229. doi:10.1016/0166-445x(94)00065-x

Bisson, M., Hontela, A., 2002. Cytotoxic and endocrine-disrupting potential of atrazine, diazinon, endosulfan, and mancozeb in adrenocortical steroidogenic cells of rainbow trout exposed in vitro. Toxicol. Appl. Pharmacol. 180, 110-117. doi:10.1006/taap.2002.9377 
Blahová, J., Plhalová, L., Hostovský, M., Divišová, L., Dobšíková, R., Mikulíková, I., Štěpánová, S.,

Svobodová, Z., 2013. Oxidative stress responses in zebrafish Danio rerio after subchronic exposure to atrazine. Food Chem. Toxicol. 61, 82-85. doi:10.1016/j.fct.2013.02.041

Bonnefoy, N., 2012. Information Report on Behalf of the Joint Mission of Information on Pesticides and Their Impact on Health and the Environment. Report of the French Senate (in French). Paris, France.

Bradford, M.M., 1976. A rapid and sensitive method for the quantitation of microgram quantities of protein utilizing the principle of protein-dye binding. Anal. Biochem. 72, 248-254. doi:http://dx.doi.org/10.1016/0003-2697(76)90527-3

Butault, J.-P., Dedryver, C.-A., Gary, C., Guichard, L., Jacquet, F., Meynard, J.-M., Nicot, P., Pitra, M., Reau, R., Sauphanor, B., Savini, I., Volay, T., 2010. Ecophyto R\&D: What Ways to Reduce the Use of Pesticides? Summary of the study report (in French). France.

Calow, P., 1991. Physiological costs of combating chemical toxicants: Ecological implications. Comp. Biochem. Phys. C. 100, 3-6. doi:10.1016/0742-8413(91)90110-F

Cericato, L., Neto, J.G.M., Fagundes, M., Kreutz, L.C., Quevedo, R.M., Finco, J., da Rosa, J.G.S., Koakoski, G., Centenaro, L., Pottker, E., Anziliero, D., Barcellos, L.J.G., 2008. Cortisol response to acute stress in jundiá Rhamdia quelen acutely exposed to sub-lethal concentrations of agrichemicals. Comp. Biochem. Phys. C. 148, 281-286. doi:10.1016/j.cbpc.2008.06.008

Cericato, L., Neto, J.G.M., Kreutz, L.C., Quevedo, R.M., da Rosa, J.G.S., Koakoski, G., Centenaro, L., Pottker, E., Marqueze, A., Barcellos, L.J.G., 2009. Responsiveness of the interrenal tissue of Jundiá (Rhamdia quelen) to an in vivo ACTH test following acute exposure to sublethal concentrations of agrichemicals. Comp. Biochem. Phys. C. 149, 363-7. doi:10.1016/j.cbpc.2008.09.002

Chellappa, S., Huntingford, F.A., Strang, R.H.C., Thomson, R.Y., 1995. Condition factor and hepatosomatic index as estimates of energy status in male three-spined stickleback. J. Fish Biol. 47, 775-787. doi:10.1111/j.1095-8649.1995.tb06002.x

Cui, Y., Liu, B., Xie, J., Xu, P., Habte-Tsion, H.M., Zhang, Y., 2014. Effect of heat stress and recovery on viability, oxidative damage, and heat shock protein expression in hepatic cells of grass carp (Ctenopharyngodon idellus). Fish Physiol. Biochem. 40, 721-729. doi:10.1007/s10695-013-9879-2

DeBerardinis, R.J., Cheng, T., 2010. Q's next: the diverse functions of glutamine in metabolism, cell biology and cancer. Oncogene 29, 313-24. doi:10.1038/onc.2009.358

De Coen, W. M. and Janssen, C. R. 1997. The use of biomarkers in Daphnia magna toxicity testing. IV. Cellular Energy Allocation: A new methodology to assess the energy budget of toxicant-stressed Daphnia populations. J. Aquat. Ecosyst. Stress Recovery.6, 43-55. 
Désautés, C., Bidanel, J.P., Mormède P. 1997. Genetic Study of Behavioral and Pituitary-Adrenocortical Reactivity in Response to an Environmental Challenge in Pigs. Physiol. Behav. 62,337-345.

Fernandez-Gomez, F.J., Galindo, M.F., Gómez-Lázaro, M., Yuste, V.J., Comella, J.X., Aguirre, N., Jordán, J., 2005. Malonate induces cell death via mitochondrial potential collapse and delayed swelling through an ROS-dependent pathway.Brit. J. Pharmacol. 144, 528-37. doi:10.1038/sj.bjp.0706069

Fernandino, J.I., Hattori, R.S., Moreno Acosta, O.D., Strüssmann, C.A., Somoza, G.M., 2013. Environmental stress-induced testis differentiation: Androgen as a by-product of cortisol inactivation. Gen. Comp. Endorc. 192, 36-44. doi:10.1016/j.ygcen.2013.05.024

Ferrando, M.D., Andreu-Moliner, E., Almar, M.M., Cebrian, C., Nuñez, a., 1987. Acute toxicity of organochlorined pesticides to the European eel, Anguilla anguilla: The dependency on exposure time and temperature. B. Environ. Contam. Tox. 39, 365-369. doi:10.1007/BF01688297

Ferreira, N.G.C., Morgado, R., Santos, M.J.G., Soares, A.M.V.M., Loureiro, S., 2015. Biomarkers and energy reserves in the isopod Porcellionides pruinosus: The effects of long-term exposure to dimethoate. Sci. Total Environ. 502, 91-102. doi:10.1016/j.scitotenv.2014.08.062

Gagné, F., Blaise, C., André, C., Salazar, M., 2006. Effects of pharmaceutical products and municipal wastewaters on temperature-dependent mitochondrial electron transport activity in Elliptio complanata mussels. Comp. Biochem. Physiol. C. 143, 388-393. doi:10.1016/j.cbpc.2006.04.013

Gagné, F., Blaise, C., André, C., Pellerin, J., 2007. Implication of site quality on mitochondrial electron transport activity and its interaction with temperature in feral Mya arenaria clams from the Saguenay Fjord. Environ. Res. 103, 238-246. doi:10.1016/j.envres.2006.05.006

Gandar, A., Jean, S., Canal, J., Marty-Gasset, N., Gilbert, F., Laffaille, P., 2015. Multistress effects on behavior and physiology of Carassius auratus. Environ. Sci. Pollut. R. 3, 3323-3331. doi:10.1007/s12192-0100223-9

Gandar, A., Laffaille, P., Marty-Gasset, N., Viala, D., Molette, C., Jean, S. 2017. Proteome response of fish under multiple stress exposure: Effects of pesticide mixtures and temperature increase. Aquat Toxicol. 184, 61-77. doi: 10.1016/j.aquatox.2017.01.004

Gamain, P., Gonzalez, P., Cachot. J., Pardon, P., Tapie, N., Gourves, P.Y., Budzinski. H., Morin, B., 2016. Combined effects of pollutants and salinity on embryo-larval development of the Pacific oyster, Crassostrea gigas. Mar. Environ. Res., 113, 31-38. doi: 10.1016/j.marenvres.2015.11.002

Gluth, G., Hanke, W., 1984. A comparison of physiological changes in Carp, Cyprinus carpio, induced by several pollutants at sublethal concentration - II. The dependency on the temperature. Comp. Biochem. Physiol. C. 79, 39-45. doi:10.1016/0742-8413(84)90160-9 
Gorbi, S., Baldini, C., Regoli, F., 2005. Seasonal variability of metallothioneins, cytochrome P450, bile

metabolites and oxyradical metabolism in the European eel Anguilla anguilla L. (Anguillidae) and striped mullet Mugil cephalus L. (Mugilidae). Arch. Environ. Con. Tox. 49, 62-70. doi:10.1007/s00244-004-0150-9

Guardiola, F.A., Gónzalez-Párraga, P., Meseguer, J., Cuesta, A., Esteban, M.A., 2014. Modulatory effects of deltamethrin-exposure on the immune status, metabolism and oxidative stress in gilthead seabream (Sparus aurata L.). Fish. Shellfish. Immun. 36, 120-9. doi:10.1016/j.fsi.2013.10.020

Guilherme, S., Gaivão, I., Santos, M.A., Pacheco, M., 2012. DNA damage in fish (Anguilla anguilla) exposed to a glyphosate-based herbicide - Elucidation of organ-specificity and the role of oxidative stress. Mutat. Res-Gen Tox. En. 743, 1-9. doi:10.1016/j.mrgentox.2011.10.017

Habig, W.H., Pabst, M.J., Jakoby, W.B., 1974. Glutathione S-Transferases. The fist enzymatic step in mercapturic acid formation. J. Biol. Chem. 249, 7130-7139.

Handy, R.D., Sims, D.W., Giles, A., Campbell, H. A., Musonda, M.M., 1999. Metabolic trade-off between locomotion and detoxification for maintenance of blood chemistry and growth parameters by rainbow trout (Oncorhynchus mykiss) during chronic dietary exposure to copper. Aquat. Toxicol. 47, $23-41$. doi:10.1016/S0166-445X(99)00004-1

Hashim, E.F., Zaki, M.S., 2005. Assessment of the hazardous effect of fungicide Dithane on Clarias lazera (catfish) including haematological, biochemical, and immunological parameters. Arab Univ. J. Agric. Sci. 13, 1005-1018.

Hayes, T.B., Case, P., Chui, S., Chung, D., Haeffele, C., Haston, K., Lee, M., Mai, V.P., Marjuoa, Y., Parker, J., Tsui, M., 2006. Pesticide mixtures, endocrine disruption, and amphibian declines: Are we underestimating the impact? Environ. Health Persp. 114, 40-50. doi:10.1289/ehp.8051

Holmstrup, M., Bindesbøl, A.M., Oostingh, G.J., Duschl, A., Scheil, V., Köhler, H.R., Loureiro, S., Soares, A.M.V.M., Ferreira, A.L.G., Kienle, C., Gerhardt, A., Laskowski, R., Kramarz, P.E., Bayley, M., Svendsen, C., Spurgeon, D.J., 2010. Interactions between effects of environmental chemicals and natural stressors: A review. Sci. Total Environ. 408, 3746-3762. doi:10.1016/j.scitotenv.2009.10.067

Hontela, A., 1997. Endocrine and physiological responses of fish to xenobiotics: Role of glucocorticosteroid hormones. Rev. Toxicol. 1, 1-46.

Jin, Y., Zhang, X., Shu, L., Chen, L., Sun, L., Qian, H., Liu, W., Fu, Z., 2010. Oxidative stress response and gene expression with atrazine exposure in adult female zebrafish (Danio rerio). Chemosphere 78, 846-852. doi:10.1016/j.chemosphere.2009.11.044

Jorgensen, C.B., 1988. Metabolic costs of growth and maintenance in the toad, Bufo bufo. J. Exp. Biol. 138, 319-331. 
Kennedy, C.J., Ross, P.S., 2012. Stress syndromes: Heightened bioenergetic costs associated with contaminant exposure at warm temperatures in teleosts. Integr. Environ. Asses. 8, 202-204. doi:10.1002/ieam.1261

Koakoski, G., Quevedo, R.M., Ferreira, D., Oliveira, T.A., da Rosa, J.G.S., de Abreu, M.S., Gusso, D., Marqueze, A., Kreutz, L.C., Giacomini, A.C.V., Fagundes, M., Barcellos, L.J.G., 2014. Agrichemicals chronically inhibit the cortisol response to stress in fish. Chemosphere 112, 85-91. doi:http://dx.doi.org/10.1016/j.chemosphere.2014.02.083

Kumar, P., Prasad, Y., Patra, A.K., Ranjan, R., Swarup, D., Patra, R.C., Pal, S., 2009. Ascorbic acid, garlic extract and taurine alleviate cadmium-induced oxidative stress in freshwater catfish (Clarias batrachus). Sci. Total Environ. 407, 5024-5030. doi:10.1016/j.scitotenv.2009.05.030

Laetz, C.A., Baldwin, D.H., Hebert, V.R., Stark, J.D., Scholz, N.L., 2014. Elevated temperatures increase the toxicity of pesticide mixtures to juvenile coho salmon. Aquat Toxicol. 146, 38-44.

Lannig, G., Cherkasov, A.S., Sokolova, I.M., 2006. Temperature-dependent effects of cadmium on mitochondrial and whole-organism bioenergetics of oysters (Crassostrea virginica). Mar. Environ. Res. 62, 7982. doi:10.1016/j.marenvres.2006.04.010

Lapointe, D., Pierron, F., Couture, P., 2011. Individual and combined effects of heat stress and aqueous or dietary copper exposure in fathead minnows (Pimephales promelas). Aquat. Toxicol. 104, 80-85. doi:10.1016/j.aquatox.2011.02.022

Lavergne, E., Pedron, N., Calves, I., Claireaux, G., Mazurais, D., Zambonino-Infante, J., Le Bayon, N., Cahu, C., Laroche, J., 2015. Does the chronic chemical contamination of a European flounder population decrease its thermal tolerance? Mar. Pollut. Bull. 95, 658-64. doi:10.1016/j.marpolbul.2015.01.006

Lemly, A.D., 1996. Winter stress syndrome: an important consideration for hazard assessment of aquatic pollutants. Ecotox. Environ. Safe. 34, 223-227. doi:10.1006/eesa.1996.0067

Li, M., Wang, J., Lu, Z., Wei, D., Yang, M., Kong, L., 2014. NMR-based metabolomics approach to study the toxicity of lambda-cyhalothrin to goldfish (Carassius auratus). Aquat. Toxicol. 146, 82-92. doi:10.1016/j.aquatox.2013.10.024

Li, M., Ruan L.Y., Zhou J.W., Fu Y.H., Jiang L., Zhao H., Wang J.S., 2017. Metabolic profiling of goldfish (Carassius auratus) after long-term glyphosate-based herbicide exposure. Aquat. Toxicol. 188, 159-169. http://dx.doi.org/10.1016/j.aquatox.2017.05.004

Lin, C.Y., Wu, H., Tjeerdema, R.S., Viant, M.R., 2007. Evaluation of metabolite extraction strategies from tissue samples using NMR metabolomics. Metabolomics 3, 55-67. doi:10.1007/s11306-006-0043-1 
López-Olmeda, J.F., Sánchez-Vázquez, F.J., 2011. Thermal biology of zebrafish (Danio rerio). J. Therm.

Biol. 36, 91-104. doi:10.1016/j.jtherbio.2010.12.005

Lushchak, V.I., 2011. Environmentally induced oxidative stress in aquatic animals. Aquat. Toxicol. 101, 13-30. doi:10.1016/j.aquatox.2010.10.006

Lyytikäinen, T., Pylkkö, P., Ritola, O., Lindström-Seppä, P., 2002. The effect of acute stress and temperature on plasma cortisol and ion concentrations and growth of Lake Inari Arctic charr, Salvelinus alpinus. Environ. Biol. Fish. 64, 195-202. doi:10.1023/A:1016017822700

Madeira, D., Narciso, L., Cabral, H., 2013. Influence of temperature in thermal and oxidative stress responses in estuarine fish. Physiol. Part A 166, 237-243. doi:http://dx.doi.org/10.1016/j.cbpa.2013.06.008

Maltby, L., Brock, T.C.M., van den Brink, P.J., 2009. Fungicide Risk Assessment for Aquatic Ecosystems: Importance of Interspecific Variation, Toxic Mode of Action, and Exposure Regime. Environ. Sci. Technol. 43, 7556-7563. doi:10.1021/es901461c

Manciocco, A., Calamandrei, G., Alleva, E., 2014. Global warming and environmental contaminants in aquatic organisms: The need of the etho-toxicology approach. Chemosphere 100, 1-7. doi:10.1016/j.chemosphere.2013.12.072

Marchand, J., Quiniou, L., Riso, R., Thebaut, M.-T., Laroche, J., 2004. Physiological cost of tolerance to toxicants in the European flounder Platichthys flesus, along the French Atlantic Coast. Aquat. Toxicol. 70, 327343. doi:http://dx.doi.org/10.1016/j.aquatox.2004.10.001

McCarty, R., 2010. Fight-or-Flight Response, in: Encyclopedia of Stress. Elsevier Inc., pp. 62-64.

Mommsen, T., Vijayan, M., Moon, T., 1999. Cortisol in teleosts: dynamics, mechanisms of action, and metabolic regulation. Rev. Fish Biol. Fish. 9, 211-268. doi:10.1023/a:1008924418720

Moon, T.W., Johnston, I. A., 1980. Starvation and the activities of glycolytic and gluconeogenic enzymes in skeletal muscles and liver of the plaice, Pleuronectes platessa. J. Comp. Physiol. B 136, 31-38. doi:10.1007/BF00688619

Nascimento, C.R.B., Souza, M.M., Martinez, C.B.R., 2012. Copper and the herbicide atrazine impair the stress response of the freshwater fish Prochilodus lineatus. Comp. Biochem. Physiol. C. 155, 456-61. doi:10.1016/j.cbpc.2011.12.002

Norris, D.O., 1997. The Mammalian Adrenal Glands and Comparative Aspects of Vertebrate Adrenals: Cortical and Chromaffin Cells, in: Norris, D.O. (Ed.), Vertebrate Endocrinology. Academic Press, New York, pp. 299-355. 
Noyes, P.D., McElwee, M.K., Miller, H.D., Clark, B.W., Van Tiem, L. A., Walcott, K.C., Erwin, K.N., Levin, E.D., 2009. The toxicology of climate change: Environmental contaminants in a warming world. Environ. Int. 35, 971-986. doi:10.1016/j.envint.2009.02.006

Nwani, C.D., Nagpure, N.S., Kumar, R., Kushwaha, B., Lakra, W.S., 2013. DNA damage and oxidative stress modulatory effects of glyphosate-based herbicide in freshwater fish, Channa punctatus. Environ. Toxicol. Phar. 36, 539-547. doi:http://dx.doi.org/10.1016/j.etap.2013.06.001

Osterauer, R., Köhler, H.R., 2008. Temperature-dependent effects of the pesticides thiacloprid and diazinon on the embryonic development of zebrafish (Danio rerio). Aquat. Toxicol. 86, 485-494. doi:10.1016/j.aquatox.2007.12.013

Pankhurst, N.W., Van Der Kraak, G., 2011. Effect of stress on reproduction and growth of fish, in: Iwama, G.K., Pickering, A.D., Sumpter, J.P., Schreck, C.B. (Eds.), Fish Stress and Health in Aquaculture. Cambridge University Press, Cambridge, UK, pp. 73-93.

Paoletti, F., Aldinucci, D., Mocali, A., Caparrini, A., 1986. A sensitive spectrophotometric method for the determination of superoxide dismutase activity in tissue extracts. Anal. Biochem. 154, 536-541. doi:http://dx.doi.org/10.1016/0003-2697(86)90026-6

Polard, T., Jean, S., Gauthier, L., Laplanche, C., Merlina, G., Sánchez-Pérez, J.M., Pinelli, E., 2011. Mutagenic impact on fish of runoff events in agricultural areas in south-west France. Aquat. Toxicol. 101, 126134. doi:10.1016/j.aquatox.2010.09.014

Regoli, F., Giuliani, M.E., 2014. Oxidative pathways of chemical toxicity and oxidative stress biomarkers in marine organisms. Mar. Environ. Res. 93, 106-117. doi:http://dx.doi.org/10.1016/j.marenvres.2013.07.006

Regoli, F., Giuliani, M.E., Benedetti, M., Arukwe, A., 2011. Molecular and biochemical biomarkers in environmental monitoring: A comparison of biotransformation and antioxidant defense systems in multiple tissues. Aquat. Toxicol. 105, 56-66. doi:10.1016/j.aquatox.2011.06.014

Rohr, J.R., Palmer, B.D., 2013. Climate change, multiple stressors, and the decline of ectotherms. Conserv. Biol. 27, 741-751. doi:10.1111/cobi.12086

Romero, L.M., 2004. Physiological stress in ecology: lessons from biomedical research. Trends Ecol. Evol. 19, 249-255. doi:http://dx.doi.org/10.1016/j.tree.2004.03.008

Romero, L.M., 2010. Fight or Flight Responses, Encyclopedia of Animal Behavior. Elsevier. doi:10.1016/B978-0-08-045337-8.00261-8

Rosemberg, D.B., da Rocha, R.F., Rico, E.P., Zanotto-Filho, A., Dias, R.D., Bogo, M.R., Bonan, C.D., Moreira, J.C.F., Klamt, F., Souza, D.O., 2010. Taurine prevents enhancement of acetylcholinesterase activity 
induced by acute ethanol exposure and decreases the level of markers of oxidative stress in zebrafish brain. Neuroscience 171, 683-92. doi:10.1016/j.neuroscience.2010.09.030

Sappal, R., MacDougald, M., Fast, M., Stevens, D., Kibenge, F., Siah, A., Kamunde, C., 2015. Alterations in mitochondrial electron transport system activity in response to warm acclimation, hypoxia-reoxygenation and copper in rainbow trout, Oncorhynchus mykiss. Aquat. Toxicol. 165, 51-63. doi:http://dx.doi.org/10.1016/j.aquatox.2015.05.014

Schiedek, D., Sundelin, B., Readman, J.W., Macdonald, R.W., 2007. Interactions between climate change and contaminants. Mar. Pollut. Bull. 54, 1845-1856. doi:10.1016/j.marpolbul.2007.09.020

Schmidlin, L., von Fumetti, S., Nagel, P., 2015. Copper sulphate reduces the metabolic activity of Gammarus fossarum in laboratory and field experiments. Aquat. Toxicol. 161, 138-145. doi:http://dx.doi.org/10.1016/j.aquatox.2015.02.005

Selye, H., 1950. Stress and the General Adaptation Syndrome. Bmj. Brit. Med. J. 1, 1383-1392. doi:10.1136/bmj.1.4667.1383

Selye, H., 1946. The General Adaptation Syndrome and the desease of adaptation. J. Clin. Endocr. Metab. 6, 117-230.

Sherwood, G.D., Rasmussen, J.B., Rowan, D.J., Brodeur, J., Hontela, A., 2000. Bioenergetic costs of heavy metal exposure in yellow perch (Perca flavescens): in situ estimates with a radiotracer (137Cs) technique. Can. J. Fish. Aquat. Sci. 57, 441-450. doi:10.1139/cjfas-57-2-441

Sinhorin, V.D.G., Sinhorin, A.P., Teixeira, J.M. dos S., Miléski, K.M.L., Hansen, P.C., Moreira, P.S.A., Kawashita, N.H., Baviera, A.M., Loro, V.L., 2014. Effects of the acute exposition to glyphosate-based herbicide on oxidative stress parameters and antioxidant responses in a hybrid Amazon fish surubim (Pseudoplatystoma sp). Ecotox. Environ. Safe. 106, 181-7. doi:10.1016/j.ecoenv.2014.04.040

Smith, R.A.J., Hartley, R.C., Cochemé, H.M., Murphy, M.P., 2012. Mitochondrial Pharmacology. Trends Pharmacol. Sci. 33, 341-52. doi:10.1016/j.tips.2012.03.010

Smith, R.W., Blaney, S.C., Dowling, K., Sturm, A., Jönsson, M., Houlihan, D.F., 2001. Protein synthesis costs could account for the tissue-specific effects of sub-lethal copper on protein synthesis in rainbow trout (Oncorhynchus mykiss). Aquat. Toxicol. 53, 265-277. doi:10.1016/S0166-445X(01)00171-0

Smolders, R., Coen, W. De, Blust, R., 2005. Integrative measures of toxicant exposure in zebra fish (Danio rerio) at different levels of biological organization, in: Ostrander, G.K. (Ed.), Techniques in Aquatic Toxicology - Volume 2. pp. 5-7.

Sokolova, I.M., Lannig, G., 2008. Interactive effects of metal pollution and temperature on metabolism in aquatic ectotherms: implications of global climate change. Clim. Res. 37, 181-201. doi:10.3354/cr00764 
Sokolova, I.M., Frederich, M., Bagwe, R., Lannig, G., Sukhotin, A. a., 2012. Energy homeostasis as an

integrative tool for assessing limits of environmental stress tolerance in aquatic invertebrates. Mar. Environ. Res. 79, 1-15. doi:10.1016/j.marenvres.2012.04.003

Sokolova, I.M., 2013. Energy-Limited Tolerance to Stress as a Conceptual Framework to Integrate the Effects of Multiple Stressors. Integr. Comp. Biol. 53, 597-608. doi:10.1093/icb/ict028

Solomon, K.R., Carr, J.A., Preez, L.H. Du, Giesy, J.P., Kendall, R.J., Smith, E.E., Kraak, G.J. Van Der, 2008. Effects of Atrazine on Fish, Amphibians, and Aquatic Reptiles: A Critical Review. Crit. Rev. Toxicol. 38, 721-772.

Solomon, K.R., Dalhoff, K., Volz, D., Van Der Kraak, G., 2013. Effect of herbicides on fish, in: Tierney, K.B., Farrell, A., Brauner, C.J. (Eds.), Organic Chemical Toxicology of Fishes. Fish Physiology: Volume 33. pp. 369-409.

Soso, A.B., Barcellos, L.J.G., Ranzani-Paiva, M.J., Kreutz, L.C., Quevedo, R.M., Anziliero, D., Lima, M., Silva, L.B. da, Ritter, F., Bedin, A.C., Finco, J.A., 2007. Chronic exposure to sub-lethal concentration of a glyphosate-based herbicide alters hormone profiles and affects reproduction of female Jundiá (Rhamdia quelen). Environ. Toxicol. Phar. 23, 308-313. doi:10.1016/j.etap.2006.11.008

Stara, A., Machova, J., Velisek, J., 2012. Effect of chronic exposure to simazine on oxidative stress and antioxidant response in common carp (Cyprinus carpio L.). Environ. Toxicol. Phar. 33, 334-43. doi:10.1016/j.etap.2011.12.019

Strobel, A., Leo, E., Pörtner, H.O., Mark, F.C., 2013. Elevated temperature and pco2 shift metabolic pathways in differentially oxidative tissues of Notothenia rossii. Comp. Biochem. Phys. B. 166, 48-57. doi:10.1016/j.cbpb.2013.06.006

Taghavi, L., Merlina, G., Probst, J.-L., 2011. The role of storm flows in concentration of pesticides associated with particulate and dissolved fractions as a threat to aquatic ecosystems - Case study: the agricultural watershed of Save river (Southwest of France). Knowl. Manag. Aquat. Ecosyst. 400, 06. doi:10.1051/kmae/2011002

Tierney, K.B., Taylor, A.L., Ross, P.S., Kennedy, C.J., 2006. The alarm reaction of coho salmon parr is impaired by the carbamate fungicide IPBC. Aquat. Toxicol. 79, 149-57. doi:10.1016/j.aquatox.2006.06.003

Trudel, M., Goto, D., Wallace, W.G., 2010. Bioenergetic responses of a benthic forage fish (Fundulus heteroclitus) to habitat degradation and altered prey community in polluted salt marshes. Can. J. Fish. Aquat. Sci. 67, 1566-1584. doi:10.1139/F10-082

Ulrich, E.L., Akutsu, H., Doreleijers, J.F., Harano, Y., loannidis, Y.E., Lin, J., Livny, M., Mading, S., Maziuk, D., Miller, Z., Nakatani, E., Schulte, C.F., Tolmie, D.E., Kent Wenger, R., Yao, H., Markley, J.L., 2008. BioMagResBank. Nucleic Acids Res. 36, D402-D408. doi:10.1093/nar/gkm957 
Valavanidis, A., Vlahogianni, T., Dassenakis, M., Scoullos, M., Press, A.I.N., Press, A.I.N., 2006.

Molecular biomarkers of oxidative stress in aquatic organisms in relation to toxic environmental pollutants.

Environ. Chem. 64, 178-189. doi:10.1016/j.ecoenv.2005.03.013

Van Der Kraak, G.J., Hosmer, A.J., Hanson, M.L., Kloas, W., Solomon, K.R., 2014. Effects of Atrazine in Fish, Amphibians, and Reptiles: An Analysis Based on Quantitative Weight of Evidence, Crit. Rev. Toxicol. 44, 166. doi:10.3109/10408444.2014.967836

Viant, M.R., Werner, I., Rosenblum, E.S., Gantner, A.S., Tjeerdema, R.S., Johnson, M.L., 2003. Correlation between heat-shock protein induction and reduced metabolic condition in juvenile steelhead trout (Oncorhynchus mykiss) chronically exposed to elevated temperature. Fish Physiol. Biochem. 29, 159-171. doi:10.1023/B:FISH.0000035938.92027.81

Verslycke, T., Roast, S. D., Widdows, J., Jones, M. B. and Janssen, C. R. 2004. Cellular energy allocation and scope for growth in the estuarine mysid Neomysis integer (Crustacea: Mysidacea) following chlorpyrifos exposure: a method comparison. J. Exp. Mar. Bio. Ecol. 306, 1-16.

Wang Y., Zhu W., Wang D., Teng M., Yan J., Miao J., Zhou Z., 2017. ${ }^{1} \mathrm{H}$ NMR-based metabolomics analysis of adult zebrafish (Danio rerio) after exposure to diniconazole as well as its bioaccumulation behavior. Chemosphere. 168, 1571-1577. http://dx.doi.org/10.1016/j.chemosphere.2016.11.157

Waring, C.P., Moore, A., 2004. The effect of atrazine on Atlantic salmon (Salmo salar) smolts in fresh water and after sea water transfer. Aquat. Toxicol. 66, 93-104. doi:10.1016/j.aquatox.2003.09.001

Wishart, D.S., Tzur, D., Knox, C., Eisner, R., Guo, A.C., Young, N., Cheng, D., Jewell, K., Arndt, D., Sawhney, S., Fung, C., Nikolai, L., Lewis, M., Coutouly, M.-A., Forsythe, I., Tang, P., Shrivastava, S., Jeroncic, K., Stothard, P., Amegbey, G., Block, D., Hau, D.D., Wagner, J., Miniaci, J., Clements, M., Gebremedhin, M., Guo, N., Zhang, Y., Duggan, G.E., Macinnis, G.D., Weljie, A.M., Dowlatabadi, R., Bamforth, F., Clive, D., Greiner, R., Li, L., Marrie, T., Sykes, B.D., Vogel, H.J., Querengesser, L., 2007. HMDB: the Human Metabolome Database. Nucleic Acids Res. 35, D521-526. doi:10.1093/nar/gkl923

Wu, H., Southam, A.D., Hines, A., Viant, M.R., 2008. High-throughput tissue extraction protocol for NMR- and MS-based metabolomics. Anal. Biochem. 372, 204-212. doi:10.1016/j.ab.2007.10.002

Xing, H., Li, S., Wang, Z., Gao, X., Xu, S., Wang, X., 2012. Oxidative stress response and histopathological changes due to atrazine and chlorpyrifos exposure in common carp. Pestic. Biochem. Phys. 103, 74-80. doi:10.1016/j.pestbp.2012.03.007

Xu, H.-D., Wang, J.-S., Li, M.-H., Liu, Y., Chen, T., Jia, A.-Q., 2015. ${ }^{1} \mathrm{H}$ NMR based metabolomics approach to study the toxic effects of herbicide butachlor on goldfish (Carassius auratus). Aquat. Toxicol. 159, 69-80. doi:10.1016/j.aquatox.2014.11.020 
817 and biochemical response of the juvenile common chinese cuttlefish, Sepiella maindroni at different 818 temperatures. Aquaculture 402-403, 127-132. doi:10.1016/j.aquaculture.2013.03.018

Zhang X., Zhong Y., Tian H., Wang W., Ru S., 2015. Impairment of the cortisol stress response mediated 820 by the hypothalamus-pituitary-interrenal (HPI) axis in zebrafish (Danio rerio) exposed to monocrotophos 821 pesticide. Comp. Biochem. Phys. C. 176-177, 10-16. http://dx.doi.org/10.1016/j.cbpc.2015.07.003Zheng, J.-L., 822 Luo, Z., Liu, C.-X., Chen, Q.-L., Tan, X.-Y., Zhu, Q., Gong, Y., 2013. Differential effects of acute and chronic zinc 823 (Zn) exposure on hepatic lipid deposition and metabolism in yellow catfish Pelteobagrus fulvidraco. Aquat. 824 Toxicol. 132-133, 173-181. doi:http://dx.doi.org/10.1016/j.aquatox.2013.02.002 
Fig. captions :

Fig. 1. PLS-DA scores (top) and loadings plot (bottom) plots of integrated ${ }^{1} \mathrm{H}-\mathrm{NMR}$ spectra of liver extracts for each time point independently.

For scores plots, each dot represents an observation (fish), projected onto first (horizontal axis) and second/third (vertical axis) PLS-DA variables. Temperature is shown in different colors: $22{ }^{\circ} \mathrm{C}$ (CONTROL) in black, $32{ }^{\circ} \mathrm{C}$ in blue; exposition to pesticides is shown in different symbols: box for nonexposed fish, four-point star for exposed fish. The black ellipse determines the $95 \%$ confidence interval, which is drawn using Hotelling's 72 statistic. For loading plot, the horizontal axis corresponds to chemical shifts (ppm) and the vertical axis the loading value. The color bar corresponds to the value of the loading in the discrimination model. The positive part of the loadings plot represents metabolites higher for group(s) in the left section of the scores plot whereas the negative part of the loadings plot represents metabolites that are higher for group(s) in the right section of the score plot. Corresponding loading plots color coded according to the correlation coefficients from blue to red. (For interpretation of the references to color in this figure legend, the reader is referred to the web version of the article.)

A. T6h liver extracts $\left(A=3, R^{2}=52.7 \%, Q^{2}=0.368\right)$. B. T96h liver extracts $\left(A=3, R^{2}=54.3 \%, Q^{2}=0.343\right)$. C. T16d liver extracts $\left(A=2, R^{2}=55.4 \%, Q^{2}=0.507\right)$. D. T6h liver extracts. $E$. T96h liver extracts. T16d liver extracts.

Fig. 2. Canonical representations of endocrine, physiological and metabolic responses of goldfish to individual and combined chemical and thermal stresses.

Fish were exposed for $6 \mathrm{~h}, 96 \mathrm{~h}$ or $16 \mathrm{~d}$ to a mixture of pesticides (PEST), temperature increased (TEMP) or a combination of pesticide mixture and temperature increased (PEST*TEMP). Integration of endocrine, metabolic and physiological responses was realized using canonical analysis and Mahalanobis distance calculs. Blue diamonds: position of variables on the first canonical plan. Red squares: mean positions of groups. Blue boxes: Mahalanobis distances between exposed groups and control group. Asterisks: significant Mahalanobis distances with *: p-value $<0.05,{ }^{* *}$ : $p$-value $<0.01$. Abbreviations: AE: available energy; EC: energy consumed; HSI: hepaosomatic index; MI: muscle index; FCF: Fulton's condition factor.

Fig. 3. Defense system induction in goldfish exposed to individual and combined chemical and thermal stresses.

The activity of CAT, SOD and GST were measured in the liver of goldfish exposed to pesticide mixture (PEST), temperature increased (TEMPS) or a combination of both stresses (PEST*TEMP). Boxplots at 6 $\mathrm{h}, 96 \mathrm{~h}$ and $16 \mathrm{~d}$ are presented. $\mathrm{N}=12$. 
Table 1. Fold-change of discriminant metabolites identified by ${ }^{1} \mathrm{H}$ NMR metabolomics approach in aqueous liver extracts of Carassius auratus exposed to pesticide mixture (PEST), temperature increased (TEMP) or both (PEST*TEMP) compared to CONTROL group at T6 $\mathrm{h}$.

\begin{tabular}{|c|c|c|c|c|c|c|c|c|}
\hline & Metabolites & Chemical shift $^{\text {a }} \delta^{1} H$ (ppm) & $\begin{array}{l}\text { FC }^{b} \\
\text { PEST }\end{array}$ & $P^{c}$ & $\begin{array}{c}\text { FC } \\
\text { TEMP }\end{array}$ & $\mathbf{P}$ & FC PEST*TEMP & $\mathbf{P}$ \\
\hline \multirow[t]{2}{*}{ Amino-acids } & Glutamine & $2.14(\mathrm{~m}), 2.45(\mathrm{~m}), 3.78(\mathrm{t})$ & 1.43 & $* *$ & 1.32 & $* *$ & 1.32 & \\
\hline & Proline & $\begin{array}{c}2.00(\mathrm{~m}), 2.04(\mathrm{~m}), 2.35(\mathrm{~m}), 3.34(\mathrm{~m}) \\
3.41(\mathrm{~m}), 4.14(\mathrm{dd})\end{array}$ & 1.15 & & 0.72 & & 0.65 & $*$ \\
\hline \multirow[t]{3}{*}{ Organic acids } & $\begin{array}{l}\text { Glutathione } \\
\text { (reduced) }\end{array}$ & $\begin{array}{c}2.17(q), 2.55(\mathrm{~m}), 2.98(\mathrm{ddd}), \\
3.80(\mathrm{~m}), 4.57(\mathrm{~m})\end{array}$ & 1.29 & $* *$ & 1.27 & $* *$ & 1.14 & \\
\hline & Succinate & $2.40(\mathrm{~s})$ & 1.29 & $* *$ & 1.00 & & 0.97 & \\
\hline & Taurine & $3.27(\mathrm{t}), 3.43(\mathrm{t})$ & 1.15 & & 1.18 & $* *$ & 1.09 & \\
\hline Sugars & Maltose & $\begin{array}{c}3.29(d d), 3.43(t), 3.56-4.00 \\
4.66(d), 5.24(d), 5.42(d)\end{array}$ & 0.91 & $* *$ & 0.99 & & 0.98 & \\
\hline \multirow[t]{2}{*}{ Phosphagens } & Choline & $3.20(\mathrm{~s}), 3.53(\mathrm{~m}), 4.07(\mathrm{~m})$ & 1.49 & $* * *$ & 1.15 & & 1.08 & \\
\hline & $\begin{array}{c}\text { Phosphoryl- } \\
\text { choline }\end{array}$ & $3.22(\mathrm{~s}), 3.60(\mathrm{~m}), 4.17(\mathrm{~m})$ & 1.31 & & 1.78 & $*$ & 1.54 & \\
\hline \multirow[t]{3}{*}{ Nucleotides } & AMP & $\begin{array}{c}4.03(\mathrm{~m}), \\
4.38(\mathrm{~m}), 4.52(\mathrm{dd}), 6.15(\mathrm{~d}), 8.24(\mathrm{~s}), 8.5 \\
6(\mathrm{~s})\end{array}$ & 1.40 & $* * *$ & 1.14 & 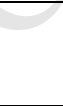 & 1.00 & \\
\hline & NAD+ & $\begin{array}{c}4.24(\mathrm{~m}), 4.35-4.44,4.47- \\
4.56,6.03(\mathrm{~d}), \\
6.10(\mathrm{~d}), 8.14(\mathrm{~s}), 8.20(\mathrm{dd}), 8.41(\mathrm{~s}), \\
8.84(\mathrm{~d}), 9.15(\mathrm{~d}) \\
\end{array}$ & 1.40 & 7 & 1.20 & & 1.08 & \\
\hline & UDP/UTP & $\begin{array}{c}4.22-4.30,4.38-4.47,5.98(\mathrm{~m}) \\
7.99(\mathrm{~d})\end{array}$ & 1.28 & & 0.79 & $* * *$ & 0.74 & $*$ \\
\hline
\end{tabular}

${ }^{a}$ Multiplicity : s, singlet; $d$, doublet; t, triplet; q, quartets; $\mathrm{m}$, multiplet. ${ }^{b} \mathrm{FC}$, Fold Change $=$ exposed samples/control samples. ${ }^{\mathrm{C}} \mathrm{P}$ values were calculated using a nonparametric Kruskal-Wallis test. ${ }^{*} \mathrm{P}<0.05,{ }^{* *} \mathrm{P}<0.01,{ }^{* * *} \mathrm{P}<0.001$.

Table 2. Fold-change of discriminant metabolites identified by ${ }^{1} \mathrm{H}$ NMR metabolomics approach in aqueous liver extracts of Carassius auratus exposed to pesticide mixture (PEST), temperature increased (TEMP) or both (PEST*TEMP) compared to CONTROL group at T96 $\mathrm{h}$.

\begin{tabular}{|c|c|c|c|c|c|c|c|c|}
\hline & Metabolites & Chemical shift ${ }^{\text {a }}{ }^{1} \mathrm{H}$ (ppm) & $\begin{array}{l}\text { FC }^{b} \\
\text { PEST }\end{array}$ & $\mathbf{P}^{c}$ & $\begin{array}{l}\text { FC } \\
\text { TEMP }\end{array}$ & $\mathbf{P}$ & $\begin{array}{c}\text { FC } \\
\text { PEST }^{*} \text { TEMP }\end{array}$ & $\mathbf{P}$ \\
\hline Amino-acids & Proline & $\begin{array}{c}2.00(\mathrm{~m}), \begin{array}{l}2.04(\mathrm{~m}), 2.35(\mathrm{~m}), 3.34(\mathrm{~m}) \\
3.41(\mathrm{~m}), 4.14(\mathrm{dd})\end{array} \\
\end{array}$ & 1.11 & & 0.69 & $* * *$ & 0.85 & $* * *$ \\
\hline \multirow[t]{2}{*}{ Organic acids } & Malonate & $3.14(s)$ & 0.87 & & 0.75 & $*$ & 0.77 & \\
\hline & Succinate & $2.40(\mathrm{~s})$ & 1.02 & & 0.92 & & 0.74 & $* *$ \\
\hline Sugars & Maltose & $\begin{array}{l}3.29(d d), 3.43(t), 3.56-4.00 \\
\quad 4.66(d), 5.24(d), 5.42(d)\end{array}$ & 1.03 & & 1.24 & $* * *$ & 1.04 & \\
\hline \multirow[t]{3}{*}{ Nucleotides } & AMP & $\begin{array}{c}4.03(\mathrm{~m}) \\
4.38(\mathrm{~m}), 4.52(\mathrm{dd}), 6.15(\mathrm{~d}), 8.24(\mathrm{~s}), 8.56(\mathrm{~s})\end{array}$ & 0.85 & $* * *$ & 0.83 & $* * *$ & 0.68 & $* * *$ \\
\hline & NAD+ & $\begin{array}{c}\text { 4.24(m), 4.35-4.44,4.47-4.56,6.03(d), } \\
6.10(\mathrm{~d}), 8.14(\mathrm{~s}), 8.20(\mathrm{dd}), 8.41(\mathrm{~s}), 8.84(\mathrm{~d}) \\
9.15(\mathrm{~d})\end{array}$ & 0.95 & & 0.82 & $* * *$ & 0.73 & $* * *$ \\
\hline & UDP/UTP & $4.22-4.30,4.38-4.47,5.98(m), 7.99(d)$ & 0.94 & & 0.72 & $* * *$ & 0.57 & $* * *$ \\
\hline \multirow[t]{2}{*}{$\begin{array}{c}\text { Non } \\
\text { identified }\end{array}$} & & $1.09(\mathrm{~d})$ & 1.00 & & 0.68 & $* * *$ & 1.50 & $* * *$ \\
\hline & & $3.09(\mathrm{~m})$ & 0.97 & & 0.72 & $* *$ & 0.91 & $* *$ \\
\hline
\end{tabular}

${ }^{a}$ Multiplicity : s, singlet; $d$, doublet; $t$, triplet; q, quartets; $\mathrm{m}$, multiplet. ${ }^{b} \mathrm{FC}$, Fold Change = exposed samples/control samples. ${ }^{\mathrm{C}} \mathrm{P}$ values were calculated using a nonparametric Kruskal-Wallis test. ${ }^{*} \mathrm{P}<0.05, * * \mathrm{P}<0.01,{ }^{* * *} \mathrm{P}<0.001$. 


\section{ACCEPTED MANUSCRIPT}

Table 3. Fold-change of discriminant metabolites identified by ${ }^{1} \mathrm{H}$ NMR metabolomics approach in aqueous liver extracts of Carassius auratus exposed to pesticide mixture (PEST), temperature increased (TEMP) or both (PEST*TEMP) compared to CONTROL group at T16 d.

\begin{tabular}{|c|c|c|c|c|c|c|c|c|}
\hline & Metabolites & Chemical shift ${ }^{\mathrm{a}} \delta^{1} \mathrm{H}(\mathrm{ppm})$ & $\begin{array}{l}\mathrm{FC}^{\mathrm{b}} \\
\mathrm{PEST}\end{array}$ & $\mathbf{P}^{c}$ & $\begin{array}{c}\text { FC } \\
\text { TEMP }\end{array}$ & $\mathbf{P}$ & $\begin{array}{c}\text { FC } \\
\text { PEST*TEMP }\end{array}$ & $\mathbf{P}$ \\
\hline \multirow[t]{7}{*}{ Amino-acids } & Alanine & $1.48(d), 3.77(q)$ & 1.01 & & 1.05 & & 0.82 & $* *$ \\
\hline & Glutamine & $2.14(\mathrm{~m}), 2.45(\mathrm{~m}), 3.78(\mathrm{t})$ & 0.97 & & 1.27 & & 0.71 & $* * *$ \\
\hline & Isoleucine & $\begin{array}{c}0.94(\mathrm{t}), 1.01(\mathrm{~d}), 1.26(\mathrm{~m}), 1.46(\mathrm{~m}) \\
1.98(\mathrm{~m}), 3.68(\mathrm{~d})\end{array}$ & 1.00 & & 0.81 & & 0.57 & $* * *$ \\
\hline & Leucine & $0.96(\mathrm{~d}), 0.97(\mathrm{~d}), 1.70(\mathrm{~m}), 3.73(\mathrm{t})$ & 0.96 & & 0.84 & & 0.55 & $* *$ \\
\hline & Lysine & $\begin{array}{c}\text { 1.44(m), 1.50(m), 1.73(m), 1.90(m), } \\
\text { 3.02(t), 3.77(t) }\end{array}$ & 1.04 & & 1.04 & & 0.68 & $* *$ \\
\hline & Proline & $\begin{array}{c}2.00(\mathrm{~m}), \begin{array}{l}2.04(\mathrm{~m}), 2.35(\mathrm{~m}), 3.34(\mathrm{~m}) \\
3.41(\mathrm{~m}), 4.14(\mathrm{dd})\end{array} \\
\end{array}$ & 0.93 & & 0.83 & $* *$ & 0.64 & $* *$ \\
\hline & Valine & $0.99(\mathrm{~d}), 1.04(\mathrm{~d}), 2.28(\mathrm{~m}), 3.62(\mathrm{~d})$ & 0.98 & & 0.92 & & 0.62 & $* * *$ \\
\hline \multirow[t]{4}{*}{ Organic acids } & Creatine & $3.04(\mathrm{~s}), 3.93(\mathrm{~s})$ & 0.94 & & 0.76 & & 0.55 & $* * *$ \\
\hline & $\begin{array}{c}\text { Glutathione } \\
\text { (reduced) }\end{array}$ & $\begin{array}{c}2.17(\mathrm{q}), 2.55(\mathrm{~m}), 2.98(\mathrm{ddd}), 3.80(\mathrm{~m}) \\
4.57(\mathrm{~m})\end{array}$ & 0.94 & & 1.65 & $* * *$ & 0.99 & \\
\hline & Lactate & $1.33(d), 4.10(q)$ & 1.05 & & 0.99 & & 0.83 & $*$ \\
\hline & Taurine & $3.27(\mathrm{t}), 3.43(\mathrm{t})$ & 1.02 & & 0.96 & & 0.86 & $* * *$ \\
\hline Sugars & Maltose & $\begin{array}{l}3.29(\mathrm{dd}), 3.43(\mathrm{t}), 3.56-4.00 \\
4.66(\mathrm{~d}), 5.24(\mathrm{~d}), 5.42(\mathrm{~d})\end{array}$ & 0.88 & & 0.99 & & 1.08 & $* * *$ \\
\hline Phosphagens & $\begin{array}{c}\text { Phosphoryl- } \\
\text { choline }\end{array}$ & $3.22(\mathrm{~s}), 3.60(\mathrm{~m}), 4.17(\mathrm{~m})$ & 1.04 & & 1.68 & $*$ & 1.18 & \\
\hline \multirow[t]{2}{*}{ Nucleotides } & AMP & $\begin{array}{c}4.03(\mathrm{~m}) \\
4.38(\mathrm{~m}), 4.52(\mathrm{dd}), 6.15(\mathrm{~d}), 8.24(\mathrm{~s}), 8.56( \\
\mathrm{s})\end{array}$ & 1.03 & & 1.08 & & 0.83 & $* *$ \\
\hline & NAD+ & $\begin{array}{c}\text { 4.24(m), } 4.35-4.44,4.47-4.56,6.03(\mathrm{~d}) \\
6.10(\mathrm{~d}), 8.14(\mathrm{~s}), 8.20(\mathrm{dd}), 8.41(\mathrm{~s}), 8.84(\mathrm{~d} \\
), 9.15(\mathrm{~d})\end{array}$ & 1.06 & & 1.12 & & 0.69 & $* * *$ \\
\hline $\begin{array}{c}\text { Non } \\
\text { identified }\end{array}$ & & $3.09(\mathrm{~m})$ & 1.12 & & 0.97 & & 0.67 & $* *$ \\
\hline
\end{tabular}

${ }^{a}$ Multiplicity : s, singlet; $d$, doublet; t, triplet; q, quartets; $\mathrm{m}$, multiplet. ${ }^{b} \mathrm{FC}$, Fold Change = exposed samples/control samples. ${ }^{\mathrm{c}} \mathrm{P}$ values were calculated using a nonparametric Kruskal-Wallis test. ${ }^{*} \mathrm{P}<0.05,{ }^{* *} \mathrm{P}<0.01,{ }^{* * *} \mathrm{P}<0.001$. 
Table 4. Endocrine, metabolic and physiological responses in goldfish exposed to individual and combined chemical and thermal stresses.

\begin{tabular}{|c|c|c|c|c|c|c|c|c|c|}
\hline \multirow[b]{2}{*}{ Variables } & \multicolumn{3}{|c|}{ T6h } & \multicolumn{3}{|c|}{ T96h } & \multicolumn{3}{|c|}{ T16d } \\
\hline & 总 & 孚 & 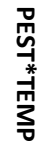 & 怘 & 굴 & 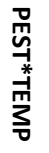 & 䍖 & $\underset{3}{\stackrel{1}{\mathbf{m}}}$ & 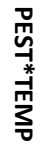 \\
\hline Cortisol & 个* & $\uparrow^{*}$ & 个* & - & - & - & - & - & $\downarrow^{\circ}$ \\
\hline \multicolumn{10}{|l|}{ Liver } \\
\hline carbohydrates & $\uparrow^{*}$ & - & $\uparrow^{\circ}$ & - & - & - & $\uparrow^{*}$ & - & - \\
\hline proteins & $\uparrow^{*}$ & $\uparrow^{* *}$ & - & - & - & - & - & - & - \\
\hline lipids & $\downarrow^{*}$ & - & - & - & - & - & - & - & - \\
\hline$A E$ & - & - & - & - & - & - & - & - & - \\
\hline EC & $\uparrow^{*}$ & $\uparrow^{* *}$ & - & - & - & - & - & - & - \\
\hline CEA & $\downarrow^{\circ}$ & - & - & - & - & - & - & - & - \\
\hline
\end{tabular}

\begin{tabular}{|c|c|c|c|c|c|c|c|c|c|}
\hline \multicolumn{10}{|l|}{ White Muscle } \\
\hline carbohydrates & - & - & - & - & - & - & - & - & - \\
\hline proteins & - & - & - & - & - & - & - & - & - \\
\hline lipids & - & $\downarrow^{\circ}$ & - & 个* & - & - & - & - & 个* \\
\hline $\mathrm{AE}$ & - & $\downarrow^{*}$ & - & $\uparrow^{*}$ & - & - & - & - & 个* \\
\hline EC & - & 个* & - & - & - & - & - & - & - \\
\hline EA & - & $\downarrow^{\star \star \star}$ & - & - & - & - & - & - & 个* \\
\hline HSI & 个** & - & - & - & - & - & $\uparrow^{*}$ & - & 个** \\
\hline MI & - & - & - & - & - & - & $\uparrow^{*}$ & - & 个** \\
\hline FCF & - & - & - & - & - & - & - & - & $\downarrow^{* \star}$ \\
\hline
\end{tabular}

Fish were exposed for 6 hours, 96 hours or 16 days to a mixture of pesticides (PEST), temperature increased (TEMP) or a combination of both (PEST*TEMP). At each time, ANOVA analyses followed by LSD post-hoc tests were performed. Red arrows indicate increased values compared to CONTROL group while green arrows correspond to decreased values. Asterisks: significance of the differences compared to CONTROL group with: ${ }^{\circ}: \mathrm{p}<0.1, *$ : $\mathrm{p}<0.05, * *$ : $\mathrm{p}<0.01,{ }^{* * *}$ : $\mathrm{p}<0.001$. Abbreviations: AE: available energy; EC: energy consumed; CEA: cellular energy allocation; HSI: hepatosomatic index; MI: muscle index; FCF: Fulton's condition factor. 


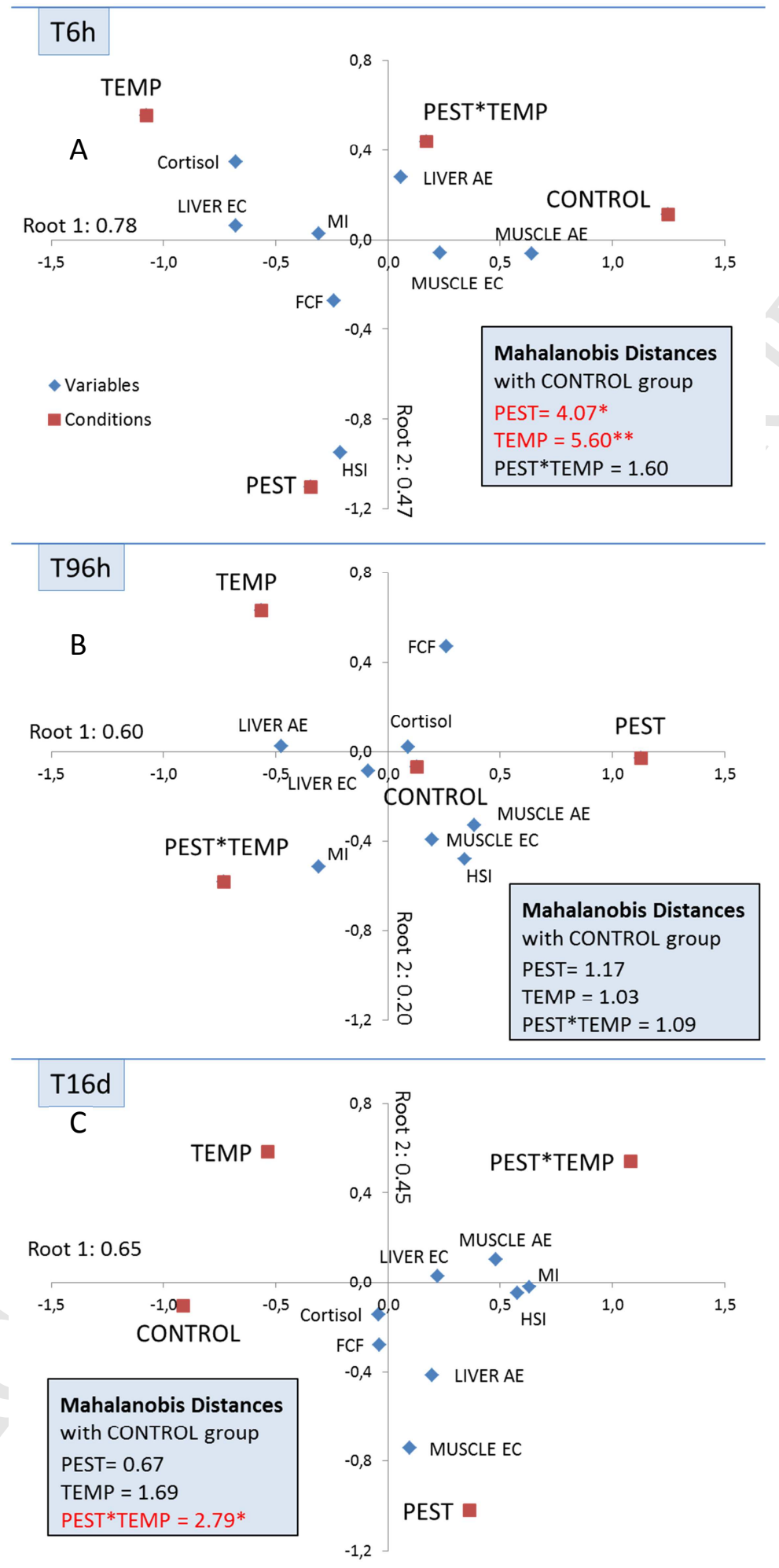

Fig. 1. Canonical representations of endocrine, physiological and metabolic responses of goldfish to individual and combined chemical and thermal stresses. 


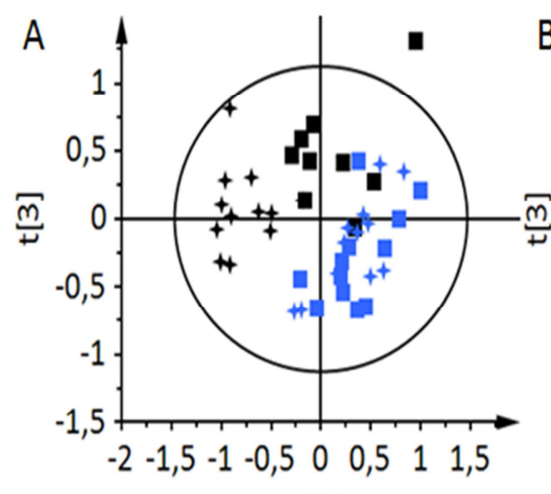

$\mathrm{t}[1]$

D

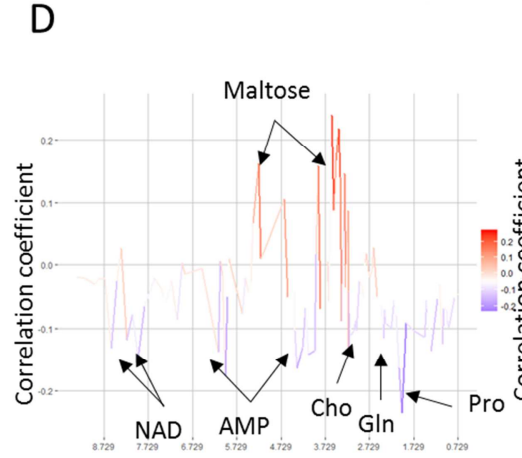

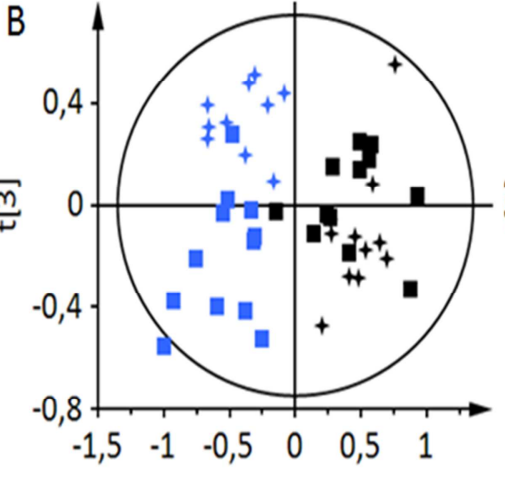

t[1]

TEMP + PEST*TEMP

$\mathrm{E}$

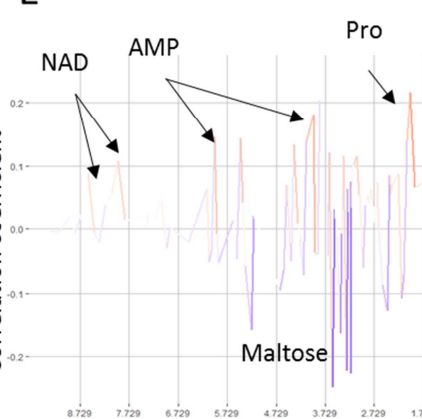

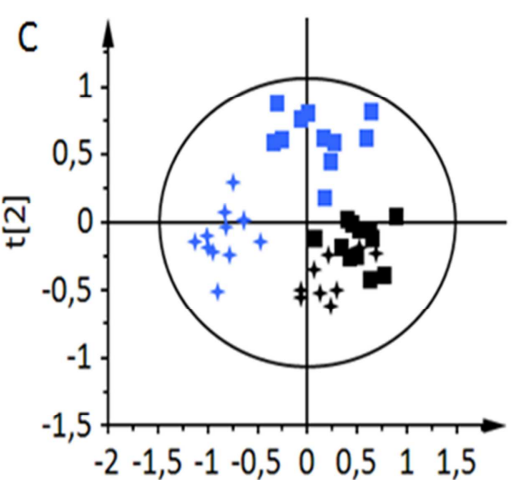

$\mathrm{t}[1]$

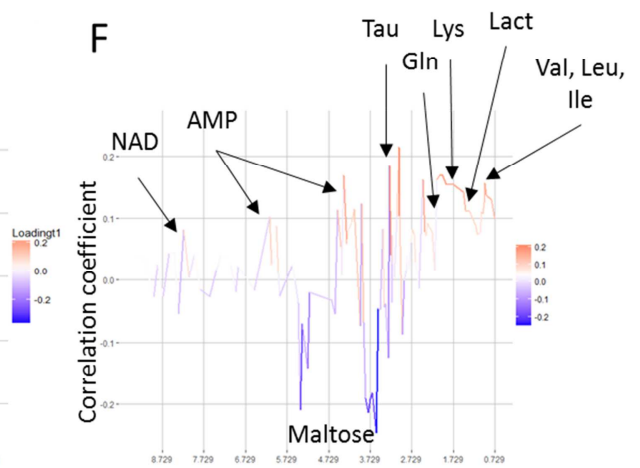

Fig. 2. PLS-DA scores (top) and loadings plot (bottom) plots of integrated ${ }^{1} \mathrm{H}$-NMR spectra of liver extracts for each time point independently. 

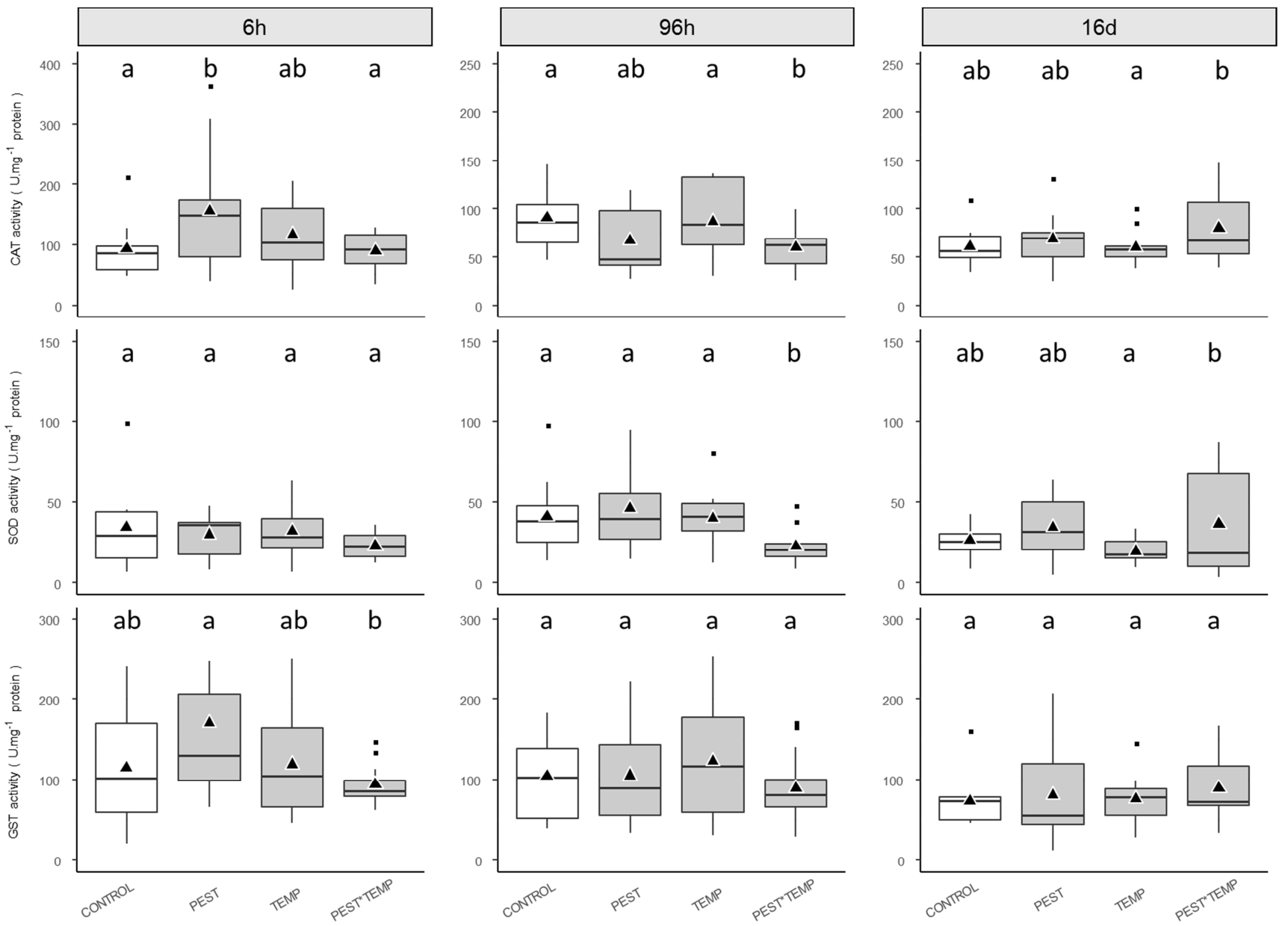

Fig. 3. Defense system induction in goldfish exposed to individual and combined chemical and thermal stresses. 
Highlights

- Goldfish were exposed to a pesticide mixture and elevated temperatures for 16 days

- Metabolomics and biochemical approaches were conducted

- Adapted and coordinated early responses to individual stressors were observed

- Multistress reduced earlier endocrine response, antioxidant defense and metabolic compensation 